\title{
Overlapping and Divergent Actions of Estrogen and the Neurotrophins on Cell Fate and p53-Dependent Signal Transduction in Conditionally Immortalized Cerebral Cortical Neuroblasts
}

\author{
Stephen B. Wade, Prem Oommen, William C. Conner, David J. Earnest, and Rajesh C. Miranda \\ Texas A \& M University Health Science Center, Department of Human Anatomy and Medical Neurobiology, College \\ Station, Texas 77843-1114
}

\begin{abstract}
The developing cerebral cortex undergoes overlapping periods of neurogenesis, suicide, and differentiation to generate the mature cortical plate. The following experiments examined the role of the gonadal hormone estrogen in comparison to the neurotrophins, in the regulation of p53-dependent cortical cell fate. To synchronize choices between neurogenesis, apoptosis, and neural differentiation, embryonic rat cerebral cortical neuroblasts were conditionally immortalized with the SV40 large T antigen containing the tsA58/U19 temperature-sensitive mutations. At the nonpermissive temperature, cessation of large $T$ antigen expression was accompanied by induction of p53, as well as the p53-dependent proteins, wild-type p53-activated fragment-1/Cdk (cyclin-dependent kinase)-interacting protein-1 (p21/Waf1), Bcl (B-cell lymphoma)-associated protein (Bax), and murine double minute 2 (MDM2), that lead to cell cyclearrest, suicide, and p53 inhibition, respectively. Simultaneously, neuroblasts exit cell cycle and die apoptotically or differentiate primarily into astrocytes and immature postmitotic neuroblasts. At the nonpermissive temperature, estrogen specifically induced an antagonist-independent increase in phosphorylated p53 expression, while increasing p21/Waf1 and decreasing
\end{abstract}

Bax. Coincidentally, estrogen rapidly increased and then decreased MDM2 relative to controls, suggesting temporal modulation of p53 function. Both estrogen and neurotrophins prevented DNA fragmentation, a marker for apoptosis. However, estrogen also induced a transient increase in released lactate dehydrogenase, suggesting that estrogen simultaneously induced rapid cell death in a subpopulation of cells. In contrast to the neurotrophins, estrogen also increased cell proliferation. Both estrogen and the neurotrophins supported neuronal differentiation. However, in contrast to the neurotrophins, estrogen only supported the expression of a subset of oligodendrocytic markers. These results suggest that estrogen and the neurotrophins support overlapping and distinct aspects of differentiation in the developing cerebral cortex.

Key words: estradiol-17 $\beta$; tamoxifen; nerve growth factor; brain derived neurotrophic factor; neurotrophin-3; neurotrophin-4; large T antigen; apoptosis; necrosis; cell cycle, bromodeoxyuridine; nestin; neurofilament; glial fibrillary acidic protein; galactocerebroside; 2',3'-cyclic nucleotide-3'-phosphodiestrase; neurons; astrocytes; oligodendrocytes; stem cells; p53; MDM2; p21/Waf1; Bax
The rat cerebral cortical neuroepithelium proliferates prenatally (Bayer and Altman, 1995) to generate mature neurons. In overlapping processes, excess neurons and neuroepithelial precursors undergo suicide (Finlay and Slattery, 1983; Ferrer et al., 1990, 1992; Spreafico et al., 1995; Blaschke et al., 1996, 1998; Rabinowicz et al., 1996; Thomaidou et al., 1997; Blaschke et al., 1998; Cheema et al., 1999). Signals that regulate choices between differentiation, suicide, and proliferation profoundly influence cortical organization.

Estrogen is one important regulator of neuronal differentiation. The two identified estrogen receptors $(\mathrm{ER} \alpha$ and $\mathrm{ER} \beta)$ are transcription factor members of the steroid hormone/retinoic acid receptor superfamily (Beato et al., 1995; Mangelsdorf et al., 1995; Kuiper et al., 1996; Mosselman et al., 1996). Nuclear estrogen

\footnotetext{
Received Dec. 22, 1998; revised April 30, 1999; accepted May 25, 1999.

This work was supported by a grant from the National Institutes of Health (MH55724) to R.C.M. We thank Drs. Wei-Jung Chen and Douglas Dohrman for their critical review of this manuscript, Zulfiqar F. Cheema, Eric Harting, and Robert E. McAlhany for technical assistance, and Dr. G. Almazan, McGill University, for the generous gift of an adenoviral vector containing the $t s$ A58/U19 large $\mathrm{T}$ antigen, in a $\psi 2$ packaging cell line.

Drs. Wade, Oommen, and Conner contributed equally to the manuscript.

Correspondence should be addressed to Dr. Rajesh C. Miranda, Texas A \& M University Health Science Center, Department of Human Anatomy and Medical Neurobiology, 232 Reynolds Medical Building, College Station, TX 77843-1114. Copyright (C) 1999 Society for Neuroscience $0270-6474 / 99 / 196994-13 \$ 05.00 / 0$
}

binding sites and $\operatorname{ER} \alpha$ mRNA are transiently expressed at high levels in the developing rodent cerebral cortex (Stumpf, 1969; Friedman et al., 1983; Gerlach et al., 1983; Shughrue et al., 1990; Miranda and Toran-Allerand, 1992; Toran-Allerand et al., 1992b; Miranda et al., 1993). ER $\beta$ is also expressed in cerebral cortex (Brandenberger et al., 1997; Shughrue et al., 1997a,b). Estrogen promotes neuritogenesis, myelination, synaptogenesis, and neurotransmitter expression in the developing brain (for review, see Miranda and Toran-Allerand, 1992; Miranda et al., 1994), while exhibiting divergent, region-specific regulation of suicide and proliferation. Thus, estrogen stimulates neuron addition to avian song control nuclei (Nordeen and Nordeen, 1989), while blocking proliferation of neuroblastomas (Ma et al., 1993) and transformed hypothalamic cells (Rasmussen et al., 1990). Similarly, estrogen has opposing region-specific effects on neuronal suicide in the differentiating hypothalamus (Rasmussen et al., 1990; Arai et al., 1996). Estrogen regulation of suicide and proliferation may therefore be context- and region-specific.

There are substantial reciprocal interactions between estrogen and the neurotrophin family of growth factors (Singh et al., 1994, 1995; Sohrabji et al., 1995; McMillan et al., 1996; Miranda et al., 1996). Neurotrophins [nerve grow th factor (NGF), brain-derived neurotrophic factor (BDNF), neurotrophin 3 (NT-3), and neurotrophin 4 (NT-4)] regulate survival and differentiation in multiple 
neural systems via two receptor classes (Chao, 1992; Davies and Wright, 1995; Chao and Hempstead, 1995). The first, the neurotrophin-selective tyrosine kinases (trks), mediate neuroprotective mechanisms. A second receptor-subtype, p75 ${ }^{\text {NTR }}$ (panneurotrophin receptor), binds all neurotrophins, modulates their interaction with trks (Hempstead et al., 1991), but can also induce suicide (Rabizadeh et al., 1993, 1994; Barrett and Bartlett, 1994; Majdan et al., 1997; Bamji et al., 1998). Estrogen downregulates p $75^{\text {NTR }}$ mRNA while upregulating trkA mRNA (Sohrabji et al., 1994a,b), suggesting that estrogen may attenuate suicide and promote survival.

Because neural proliferation, suicide, and differentiation occur asynchronously, we conditionally immortalized cerebral cortical precursors using a temperature sensitive mutation of the SV40 large $\mathrm{T}$ antigen to synchronize neural development. Previous reports indicate that inhibition of large $\mathrm{T}$ antigen expression induces cell cycle arrest, differentiation, and cell suicide (Almazan and McKay, 1992; Yanai and Obinata, 1994; Taher et al., 1995; Eves et al., 1996). Initial experiments characterized the conditional regulation of neural cell fate using this model system. The second set of experiments examined the effects of estrogen in comparison to the neurotrophins on p53-regulated survival and differentiation in the developing cerebral cortex, after cessation of large $\mathrm{T}$ antigen expression.

\section{MATERIALS AND METHODS}

\section{Creation of a conditionally immortalized cell line from embryonic rat cerebral cortex}

Timed-pregnant rats (Sprague Dawley) were obtained from Harlan (Houston, TX). Embryonic day zero (E0) was defined as the day on which dams were sperm-positive. Cingulate and isocortical tissue were dissected out from four E15 rat brains, under sterile conditions, separated from meningeal tissue, and stored in ice-cold Dulbecco's PBS (D-PBS; without $\mathrm{Ca}^{2+}$ or $\mathrm{Mg}^{2+}$ ) and $0.1 \%$ (w/v) glucose. Tissues were dissociated by trituration in $0.5 \%$ trypsin and $6.8 \mathrm{~mm}$ EDTA and plated on mouse laminin-coated $(0.1 \mathrm{mg} / \mathrm{ml}$; Life Technologies, Gaithersburg, MD) microtiter plates. Cultured cells were immortalized (Almazan and McKay, 1992) by infection with a mouse adenovirus containing the SV40 large T antigen (carrying both the tsA58 and U19 mutations) and antibiotic (G418) resistance cassette (adenoviral vector in $\psi 2$ packaging cell line was a gift of G. Almazan, McGill University, Montreal, Quebec, Canada). Cultures were infected with replication-incompetent adenovirus in $\psi 2$ (the packaging cell line)-conditioned medium containing DMEM, $10 \%$ fetal calf serum (FCS), $100 \mathrm{U} / \mathrm{ml}$ penicillin-streptomycin, and $2 \mu \mathrm{g} / \mathrm{ml}$ hexadimethrine bromide (Sigma, St. Louis, MO). Infected cells were selected for antibiotic (G418) resistance, and cultures of clonally restricted cells were isolated. We selected one culture (CHB50) originating from multiple clonal colonies to specifically enhance the representation of divergent phenotypic fates. CHB50 cells were propagated in serum-containing culture medium (89\% DMEM with $10 \%$ FCS, $100 \mathrm{U} / \mathrm{ml}$ penicillin-streptomycin, and $50 \mu \mathrm{g} / \mathrm{ml}$ of $\mathrm{G} 418$ ) at $33^{\circ} \mathrm{C}$ (permissive temperature for large $\mathrm{T}$ antigen expression). Cultures were plated at an initial density of $\sim 10^{3}$ cells $/ \mathrm{cm}^{2}$ and at $80-85 \%$ confluence, were switched to $39^{\circ} \mathrm{C}$ (nonpermissive temperature for large $\mathrm{T}$ antigen expression) in defined, serum-free medium (49\% DMEM, 49\% F-12 nutrient medium (HAM), $1 \%$ N2 supplement, and $100 \mathrm{U} / \mathrm{ml}$ penicillinstreptomycin) for all experiments, to synchronize activation of p53 and p53-dependent processes.

\section{Characterization of tsSV-40 large T antigen-immortalized CHB50 cells}

Immunohistochemical analysis of the temperature dependence of large $T$ antigen expression

To determine if large $\mathrm{T}$ antigen expression was temperature-dependent, immunohistochemical analysis was performed on CHB50 cells cultured at $33^{\circ} \mathrm{C}$ (the permissive temperature) and at $39^{\circ} \mathrm{C}$. Cells were fixed for 30 min in $4 \%$ phosphate-buffered paraformaldehyde and $2.5 \%$ dimethylsulfoxide (DMSO). After fixation, the cells were washed three times in cold
Tris-buffered saline (TBS; $\mathrm{pH}$ 7.4), blocked with a solution containing $5 \%$ normal horse serum, TBS, $1 \%$ BSA, and $0.3 \%$ Triton $\mathrm{X}-100$, and then incubated overnight at $4^{\circ} \mathrm{C}$ with a monoclonal, anti-large $\mathrm{T}$ antigen antibody (1:200, Oncogene) in blocking solution. Binding of the primary antibody was detected using a biotinylated secondary antibody (horse anti-mouse, rat adsorbed at 1:100; Vector Laboratories, Burlingame, CA), conjugated to an avidin-biotin-horseradish peroxidase complex (ABC elite kit; Vector Laboratories) and a chromogenic substrate $\left(\mathrm{Ni}^{+}\right.$diaminobenzidine; Vector Laboratories).

\section{Live-dead assay}

To determine the viability of CHB50 cells when incubated at the nonpermissive temperature for large $\mathrm{T}$ antigen expression, cells were incubated at $33^{\circ} \mathrm{C}$ for $5 \mathrm{~d}$ or at $39^{\circ} \mathrm{C}$ for either 3 or $6 \mathrm{~d}$ using the control culture conditions described above. At the end of the culture period, live cultures were washed twice in D-PBS (Life Technologies) and incubated at room temperature with ethidium homodimer $(4 \mu \mathrm{M})$ and calcein-AM $(2 \mu \mathrm{M})$ in D-PBS according to the kit manufacturer's instructions (Molecular Probes, Eugene, OR). At the end of the incubation period, cells were rinsed three times in D-PBS and sealed in D-PBS with a glass coverslip. The living cultures were immediately photographed using epifluorescence microscopy.

\section{Detection of apoptotic nuclei}

CHB50 cells maintained at $33^{\circ} \mathrm{C}$ or at $39^{\circ} \mathrm{C}$ for $24 \mathrm{hr}$, were fixed with $4 \%$ paraformaldehyde and $2.5 \%$ DMSO at room temperature. DNA fragmentation characteristic of apoptosis was detected by TUNEL assay using a kit (Oncor) modified for alkaline phosphatase histochemistry. Cultures were exposed to equilibration buffer. Fragmented nuclear DNA was $3^{\prime}$-end labeled with digoxigenin-dUTP using terminal deoxynucleotidyl transferase. Incorporated digoxigenin-dUTP were detected using an alkaline phosphatase-conjugated anti-digoxigenin antibody (Fab fragment, Boehringer Mannheim, Indianapolis, IN) and chromogenic reaction using 4-nitroblue tetrazolium chloride and 5-bromo-4-chloro-3indolyl-phosphate as substrates.

\section{Western immunoblot analysis}

The large $\mathrm{T}$ antigen maintains cells in cell cycle by inactivating cellular check-point proteins such as p53 and inhibiting the expression of p53dependent proteins such as wild-type p53-activated fragment-1/Cdk (cyclin-dependent kinase)-interacting protein-1 (p21/Waf1/Cip1), Bcl [B-cell lymphoma]-associated protein (Bax), and murine double minute 2 (MDM2) (Levine, 1997). These proteins induce cell cycle arrest, suicide, and p53 inhibition, respectively. We therefore examined the conditional expression of these proteins by Western immunoblot analysis, according to our previously published protocols (Donovan et al., 1995; Miranda et al., 1996; Cheema et al., 1999). Phosphorylation of the casein kinase II-sensitive site at serine 392 was used as a marker for activated p53. Phosphorylation of this site promotes tetramerization of p53 (Sakaguchi et al., 1997) and specificity of p53 binding to DNA (Hoffmann et al., 1998), while regulating reannealing of double stranded DNA (Filhol et al., 1996). The expression of ER $\alpha$, TrkB, and TrkC was also analyzed. Cultures of CHB50 cells were propagated at $33^{\circ} \mathrm{C}$ to $80 \%$ confluence and analyzed in this condition, or alternatively after transfer to $39^{\circ} \mathrm{C}$ for 1,3 , or $5 \mathrm{~d}$. Detergent $(1 \% \mathrm{SDS})$-soluble protein was isolated using the Trizol reagent (Life Technologies) following the manufacturer's instructions. Protein $(25 \mu \mathrm{g} /$ lane $)$ was size-fractionated on an 8 or $15 \%$ polyacrylamide-SDS gel and electrophoretically transferred to supported nitrocellulose (Hibond-C-super; Amersham, Arlington Heights, IL). Blots were blocked [5\% milk, TBS ( $1.4 \mathrm{~m} \mathrm{NaCl}, 0.2 \mathrm{M}$ Tris, $\mathrm{pH} 7.4)$, and $0.1 \%$ Tween 20], exposed to primary antibodies [rabbit polyclonal, anti-phosphoserine392-p53 ( pp 53; 1:500; New England Biolabs, Beverly, MA), mouse monoclonal, anti-P21/Waf1/Cip1 (1:333; Calbiochem, La Jolla, CA); rabbit polyclonal anti-Bax (1:500; Santa Cruz Biotechnology, Santa Cruz, CA); mouse monoclonal anti-MDM2 (1:500; Santa Cruz Biotechnology), mouse monoclonal anti-proliferating cell nuclear antigen (PCNA; 1:66; Calbiochem), mouse monoclonal anti-ER $\alpha$ antibody (1:500; Affinity Bioreagents), mouse monoclonal anti-TrkB antibody (1:500; Transduction Laboratories, Lexington, KY), or rabbit polyclonal anti-TrkC (1:500; Santa Cruz Biotechnology)], washed, and exposed to secondary antibody [biotinylated horse anti-mouse (Vector Laboratories) at 1:5000 or biotinylated donkey anti-rabbit (Jackson ImmunoResearch, West Grove, PA) at 1:2000], washed again, and exposed to streptavidin horseradish-peroxidase conjugate (Amersham). Immunore- 
active bands were detected using enzyme-linked chemiluminescence (NEN).

\section{Role of estrogen and the neurotrophins in CHB50 cells maintained at the nonpermissive temperature for large $\mathbf{T}$ antigen expression}

\section{Regulation of cell density during differentiation $\left(39^{\circ} \mathrm{C}\right)$}

For the initial experiment on the regulation of cell number, CHB50 cells were differentiated at $39^{\circ} \mathrm{C}$ for $5 \mathrm{~d}$ in the presence of either control medium or estradiol- $17 \beta$ (at 10,2 , or $0.4 \mathrm{~nm}$; water-soluble estrogen was obtained from Sigma), or for comparison, one of the neurotrophins (human recombinant NGF, BDNF, NT-3, or NT-4; Peprotech, Rocky Hill, NJ) at $50 \mathrm{ng} / \mathrm{ml}$. After $5 \mathrm{~d}$ in vitro, cultures were fixed with $4 \%$ paraformaldehyde and $2.5 \%$ DMSO for $30 \mathrm{~min}$ at room temperature and stained with hematoxylin and eosin.

In subsequent experiments, estradiol- $17 \beta$ was administered to cultures at $2 \mathrm{nM}$. Because the neurotrophins BDNF, NT-3, and NT-4 had similar effects on cell density, they were combined together as a cocktail (each at $50 \mathrm{ng} / \mathrm{ml}$ ). NGF was omitted from the neurotrophin cocktail because this first experiment indicated that it had no effect on cell density. In some experiments, the estrogen receptor antagonist 4-hydroxytamoxifen (at 1 $\mu \mathrm{M})$ was administered along with estradiol- $17 \beta$.

\section{Regulation of cell death at $39^{\circ} \mathrm{C}$}

Detection of apoptotic profiles. CHB50 cells were maintained at $39^{\circ} \mathrm{C}$ in the presence of control medium, estradiol-17 $\beta$ ( $2 \mathrm{nM})$ or neurotrophin cocktail (BDNF, NT-3, and NT-4, each at $50 \mathrm{ng} / \mathrm{ml}$ ) for $48 \mathrm{hr}$. Cells were then fixed, and apoptotic nuclei were detected by TUNEL assay, as described above.

Lactate dehydrogenase assay. CHB50 cells were maintained at $39^{\circ} \mathrm{C}$ and given either neurotrophin cocktail (BDNF, NT-3, and NT-4, each at 50 $\mathrm{ng} / \mathrm{ml})$, or estradiol-17 $\beta$ ( $2 \mathrm{nM})$ supplements in culture medium for 5 consecutive days. Lactate dehydrogenase (LDH) activity released into the culture medium was assayed using a cytotoxicity detection kit (Boehringer Mannheim). LDH release into culture medium is a measure of cell membrane lysis caused by necrotic cell death, which correlates well with other measures of cell membrane damage (Noraberg et al., 1998). Briefly, culture-conditioned media was obtained every $24 \mathrm{hr}$ and rendered cellfree by centrifugation. We added $100 \mu \mathrm{l}$ of conditioned medium from each sample to a 96-well microtiter plate. LDH activity was measured by a redox reaction that couples the oxidation of lactate to pyruvate with the reduction of the chromogenic substrate iodotetrazolium chloride to a colored formazan salt, using NADH as the electron transfer agent and $\mathrm{NADH}$ diaphorase as the catalyst. Absorbance of samples was measured at $490 \mathrm{~nm}$ against a reference wavelength of $630 \mathrm{~nm}$ using a microtiter plate reader (ELx808; Biotek Instruments). LDH levels were quantified against a panel of LDH standards ranging in concentration from $0.001 \mathrm{nM}$ to $1 \mu \mathrm{M}$.

\section{Bromodeoxyuridine incorporation}

CHB50 cells were cultured on 96-well microtiter plates and differentiated for 5 consecutive days in the presence of a daily dose of $100 \mu \mathrm{M}$ 5-Bromo-2'-deoxyuridine (BrdU, a marker of DNA replication) alone, or BrdU with a neurotrophin cocktail (BDNF, NT-3, and NT-4) or estradiol $17 \beta$. Changes in cell proliferation were quantified using a colorimetric ELISA assay for incorporated BrdU, using a kit (Boehringer Mannheim). Briefly, culture medium was aspirated, and the cells were fixed for $30 \mathrm{~min}$ with $200 \mu \mathrm{l} /$ well of the kit-supplied fixation/denaturation solution. Cells were incubated for 120 min with anti-BrdU antibody conjugated to peroxidase, $100 \mu \mathrm{l} /$ well. Cells were washed and then exposed to chromogenic substrate solution (tetramethylbenzidine) for $30 \mathrm{~min}$. The absorbance was measured at $340 \mathrm{~nm}$ against a reference wavelength of $490 \mathrm{~nm}$ using a microtiter plate reader (ELx808; Biotek Instruments).

Estrogen and neurotrophin regulation of P21/Waf1, Bax, and MDM2

CHB50 cultures were maintained at $39^{\circ} \mathrm{C}$ for $1-5 \mathrm{~d}$ and exposed to estradiol $17 \beta$, neurotrophin cocktail, or control medium. At the end of the treatment period $(1,3$, or $5 \mathrm{~d})$, detergent-soluble protein was isolated from cultures and processed for Western immunoblot analysis as described earlier.

\section{Immunofluorescence for neural differentiation markers}

Immunohistochemistry was carried out on CHB50 cells cultured at $33^{\circ} \mathrm{C}$ or after differentiation at $39^{\circ} \mathrm{C}$ for $5 \mathrm{~d}$. Cells cultured at $39^{\circ} \mathrm{C}$ were maintained in the presence of estradiol $17 \beta$, neurotrophin cocktail, or control medium. In addition, some $39^{\circ} \mathrm{C}$ cultures were also treated with retinoic acid at $10^{-9} \mathrm{M}$ for $5 \mathrm{~d}$, to compare the expression of neuronal phenotypes with that of estrogen and neurotrophin-treated cultures. Retinoic acid is a ligand for another member of the steroid hormone receptor family (Beato et al., 1995). It is known to interact with the neurotrophins (Kaplan et al., 1993) and promotes neuronal differentiation and neurofilament expression in murine embryonic stem cells (Chen et al., 1997; Erhardt et al., 1997). Cells were fixed with 4\% paraformaldehyde and $2.5 \%$ DMSO for $30 \mathrm{~min}$. After fixation, cells were washed with TBS and blocked for $30 \mathrm{~min}$ in a TBS buffer containing $2 \%$ donkey serum, $0.3 \%$ Triton X-100, and $0.1 \%$ BSA. Cells were incubated with antibodies for neuroepithelial stem cells [mouse monoclonal anti-nestin (Chemicon)], neuronal markers [cocktail of rabbit polyclonal anti-150 and $200 \mathrm{kDa}$ neurofilament protein (Genosys)], astrocytic markers [rabbit polyclonal anti-glial fibrillary acidic protein (GFAP; Sigma)], or for oligodendrocytic markers [mouse monoclonal anti-2', $3^{\prime}$-cyclic nucleotide-3'-phosphodiestrase (CNPase; Sigma) or rabbit antigalactocerebroside (Sigma)], overnight at $4^{\circ} \mathrm{C}$. Antibodies were used at a dilution of 1:500. Binding of the primary antibody was detected using a biotinylated secondary antibody [donkey-anti rabbit at 1:500; The Jackson Laboratory, Bar Harbor, ME or horse anti-mouse (rat-adsorbed) at 1:100, Vector Laboratories] conjugated to avidin-rhodamine. Cells were then counterstained with bis-benzamide (Hoechst dye \#33258) to visualize nuclear DNA.

\section{Data analysis}

To examine the effects of treatment on cell number, hematoxylin-eosin stained cells were counted at a $100 \times$ magnification. Eight fields (two per quadrant) were counted in each well, and the number of cells was averaged to generate one sample. To examine the effect of treatment on apoptosis, the number of TUNEL-positive cells and the total number of cells per field were counted at $100 \times$ magnification. Six fields were counted within each culture well and averaged to produce one sample. The number of TUNEL-positive cells was expressed as a proportion of the total number of cells within the field. Western immunoblots were analyzed using a standard densitometric package (Molecular Analyst; Bio-Rad, Hercules, CA), and molecular weights were determined using Sigmagel (SPSS). Changes in cell number, apoptosis, released LDH activity, protein expression, and BrdU incorporation were analyzed using a standard statistical package (SPSS) to perform ANOVAs followed by post hoc Fisher's least significance difference tests with a significance level set at $p<0.05$. A sample of $6-11$ cultures was used for each experimental group. Quantitative data were expressed in terms of mean \pm SEM.

\section{RESULTS}

\section{Characterization of CHB50 cells}

\section{Immunohistochemistry for the large T antigen}

Immunohistochemical analysis indicated that the tsU19-SV40 large $\mathrm{T}$ antigen is expressed in the nuclei of cells cultured at $33^{\circ} \mathrm{C}$ (Fig. $1 \mathrm{~A}$ ). In contrast, cells cultured at $39^{\circ} \mathrm{C}$ for $5 \mathrm{~d}$ did not express large $\mathrm{T}$ antigen immunoreactivity (Fig. $1 B$ ).

\section{Conditional regulation of cell survival and cell death}

The live-dead assay indicated that there was virtually no cell death at $33^{\circ} \mathrm{C}$ (permissive temperature for large $\mathrm{T}$ antigen expression, Fig. $1 C$ ). However, at $39^{\circ} \mathrm{C}$ (the nonpermissive temperature for large $\mathrm{T}$ antigen expression), there was an induction of cell death (Fig. 1D). Analysis of DNA fragmentation by TUNEL assay indicated that the cell death occurred, in part, by apoptosis (Fig. 1, compare $E, F$ ). However, analysis of $\mathrm{LDH}$ released into culture medium, a measure of necrosis, indicated that necrotic cell death also occurred at $39^{\circ} \mathrm{C}$ (Fig. $4 B$ ). Furthermore, there were distinct changes in the morphology of cells cultured at $39^{\circ} \mathrm{C}$ as compared with those at $33^{\circ} \mathrm{C}$. At $33^{\circ} \mathrm{C}, \mathrm{CHB} 50$ cells expressed an epitheliod morphology, whereas at $39^{\circ} \mathrm{C}$, there was a marked increase in the formation of processes and stellate-type morphologies (Fig. 1, compare $C, D$ ). 
Figure 1. Characterization of CHB50 cells at the permissive temperature $\left(33^{\circ} \mathrm{C} ; A, C, E\right)$ and nonpermissive temperature $\left(39^{\circ} \mathrm{C} ; B, D, F\right)$ for large T antigen expression. ( $A$, $B$ ) Nuclear localization of large $\mathrm{T}$ antigen was observed at $33^{\circ} \mathrm{C}(A$, arrow $)$ but not at $39^{\circ} \mathrm{C}(B$, arrow $) . C, D$, The Live-dead stain showed at $33^{\circ} \mathrm{C}(C)$, virtually all cells in the dish stain green (live) and are epitheliod in shape, whereas, at $39^{\circ} \mathrm{C}(D)$, cells stain both green (live) and red (dead). Arrow indicates differentiated live cell with elongated process. $E, F$, TUNEL analysis of DNA fragmentation indicated that there was virtually no apoptosis at $33^{\circ} \mathrm{C}(E)$, whereas apoptotic profiles (blue nuclei, arrow) could be observed at $39^{\circ} \mathrm{C}(F)$. Scale bar, $70 \mu \mathrm{m}$. $33^{\circ} \mathrm{C}$
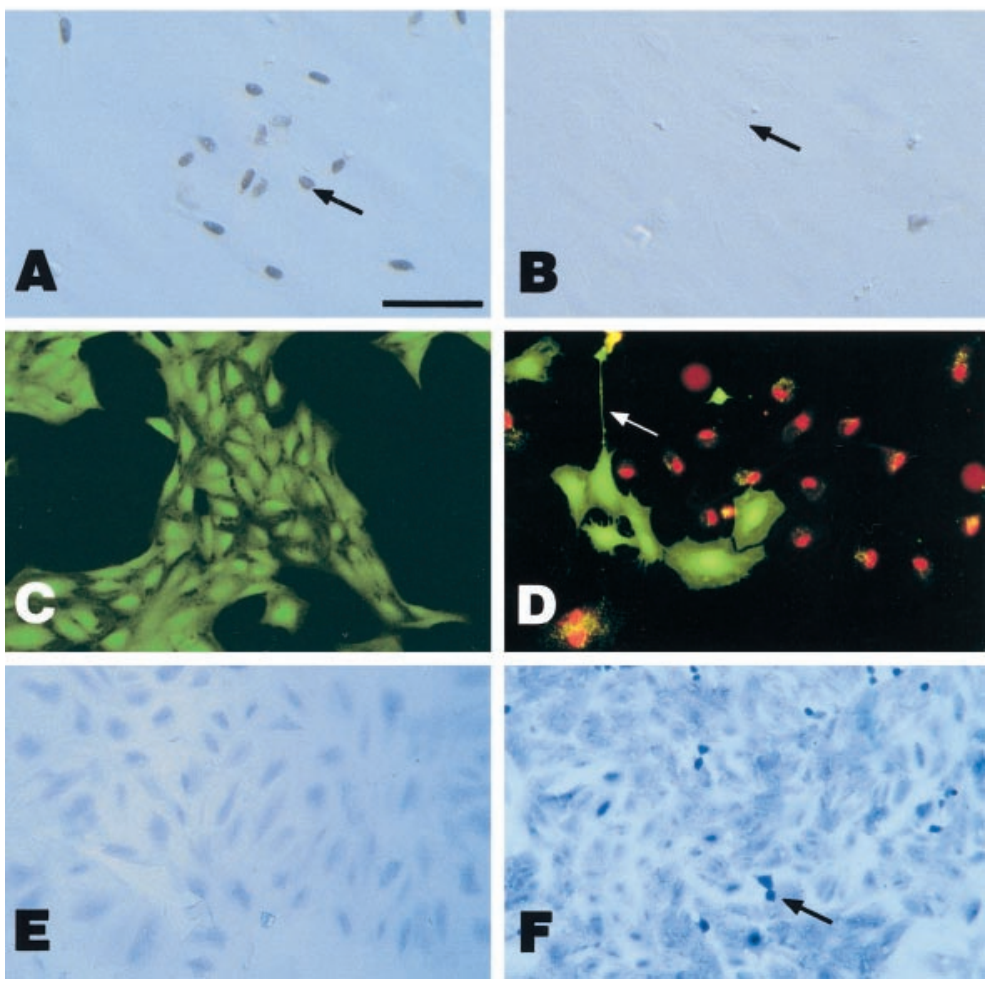

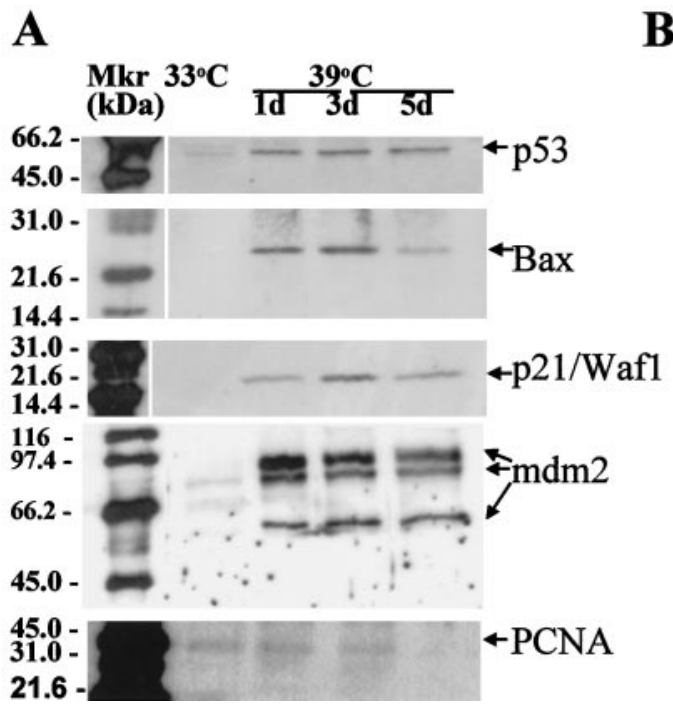

B

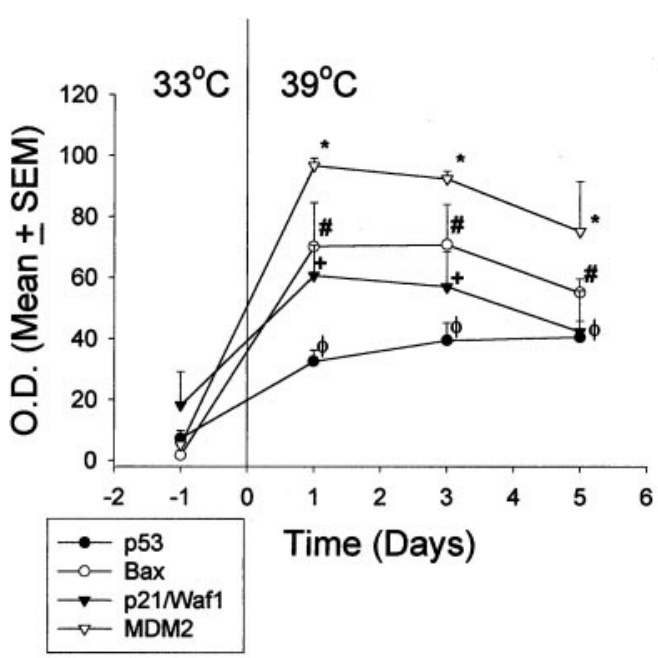

Figure 2. A, Representative samples of Western immunoblot analysis depicting the temperature-dependent expression of $p$ p53, p21/Waf1, Bax, MDM2 (p85, p68, and p57 species) and PCNA. B, Graph represents densitometric analysis of pp53, Bax, p21/Waf1, and MDM2 (p85) expression. Asterisk indicates statistically significant difference relative to expression at $33^{\circ} \mathrm{C}$. $M k r$, Molecular weight marker; $O$. D., optical density.

\section{Conditional regulation of p53 and P53-dependent genes}

Western immunoblot analysis (Fig. $2 A, B$ ) indicated that CHB50 cells cultured at $33^{\circ} \mathrm{C}$ expressed low to undetectable levels of phosphorylated p53 ( $p$ p53, phosphoserine392-p53), p21/Waf1 (cell cycle arrest protein), and Bax (the pro-apoptosis protein). In contrast, detectable levels of the cell cycle-associated protein PCNA were observed. In blots probed for MDM2 (the P53 inhibitor), three distinct bands were observed, with mean molecular weights of 85,68 , and $57 \mathrm{kDa}$, respectively, corresponding in size to previously described alternate species [85-90, 74, and 57-58 kDa, (Olson et al., 1993)] generated by alternative splicing or caspase cleavage (Erhardt et al., 1997). Although low levels of the $68 \mathrm{kDa}$ protein were observed at $33^{\circ} \mathrm{C}$, the full length $85 \mathrm{kDa}$ protein (that complexes with $\mathrm{p} 53$ ), and the $57 \mathrm{kDa}$ species [a caspase-cleaved product (Chen et al., 1997; Erhardt et al., 1997)], were undetectable. However, at $39^{\circ} \mathrm{C}$, there was a significant increase in the expression of pp53, p21/Waf1, and Bax as well as MDM2 (full length $85 \mathrm{kDa}$ and caspase-cleaved $57 \mathrm{kDa}$ species). 

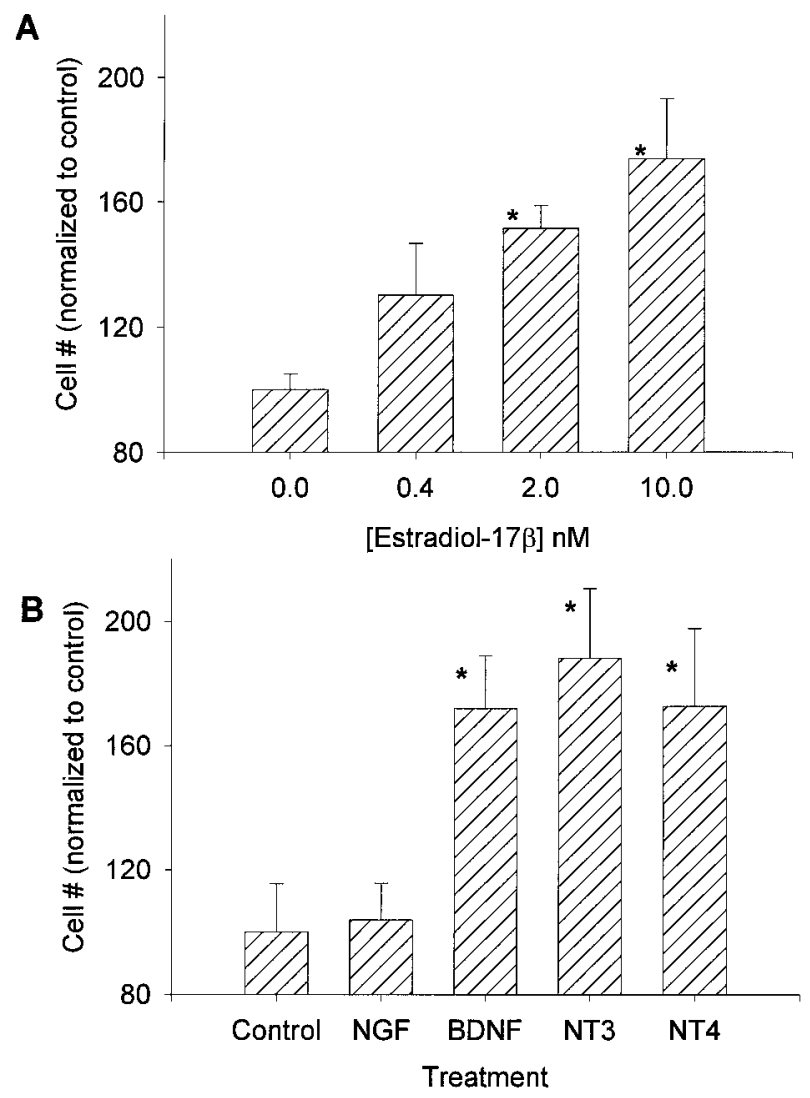

Figure 3. Graphs showing changes in cell density after treatment with estrogen $(A)$ or the neurotrophins $(B)$ for $5 \mathrm{~d}$ at $39^{\circ} \mathrm{C}$. Estradiol- $17 \beta$, BDNF, NT-3, and NT-4 led to a significant (indicated by an asterisk) increase in mean cell density relative to controls.

The expression of $p$ p53 was increased 5.6-fold. Among the p53dependent proteins, Bax showed the highest level of conditional induction (39-fold) followed by MDM2 (18.6-fold for the $85 \mathrm{kDa}$ species), whereas $\mathrm{p} 21 / \mathrm{Waf} 1$ showed the smallest, although statistically significant induction (3.3-fold). Because the $85 \mathrm{kDa}$ MDM2 protein is full length and functional (Olson et al., 1993), subsequent analysis focused on this species.

\section{Regulation of cell density at $39^{\circ} \mathrm{C}$}

$\mathrm{CHB} 50$ cells were cultured for $5 \mathrm{~d}$ at $39^{\circ} \mathrm{C}$, the nonpermissive temperature for large $\mathrm{T}$ antigen expression. Exposure to estradiol-17 $\beta$ led to a significant, dose-related increase in the density of surviving cells compared with controls (Fig. 3A). Similarly, the neurotrophins BDNF, NT-3, and NT-4 also led to a significantly greater density of $\mathrm{CHB} 50$ cells as compared with untreated controls (Fig. 3B). In contrast, the neurotrophin NGF had no effect on cell number (Fig. $3 B$ ) and was therefore eliminated from subsequent experiments. Western immunoblot analysis (Fig. 4) indicated that differentiating CHB50 cells express $\mathrm{ER} \alpha$ [expected molecular weight (MW) $\sim 64 \mathrm{kDa}$, corresponding to a similar size in uterine tissue (data not shown)], TrkB (expected $\mathrm{MW} \sim 145 \mathrm{kDa}$ ), and TrkC (expected MW $\sim 135 \mathrm{kDa}$ ). In a second set of experiments, cultures were exposed to $2 \mathrm{~nm}$ estradiol-17 $\beta$ alone or concurrently with the antagonist 4-hydroxytamoxifen at $1 \mu \mathrm{M}$ (Fig. 5). Tamoxifen prevented the estrogen-related increase in cell survival and differentiation. Furthermore, CHB50 cells concurrently treated with tamoxifen exhibited extensive cytoplasmic granulation and condensation. Be-

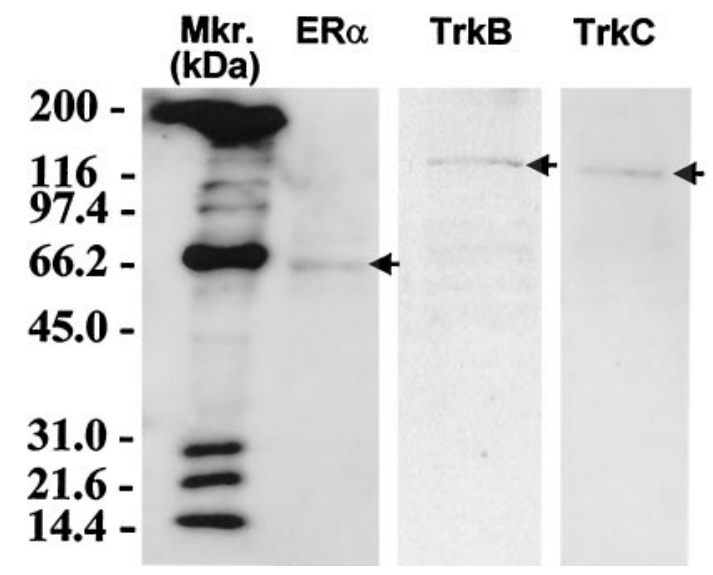

Figure 4. Western immunoblot analysis of $\mathrm{ER} \alpha$ and the neurotrophin receptors TrkB and TrkC shows the expression of immunoreactive bands of the expected molecular weight (arrows).
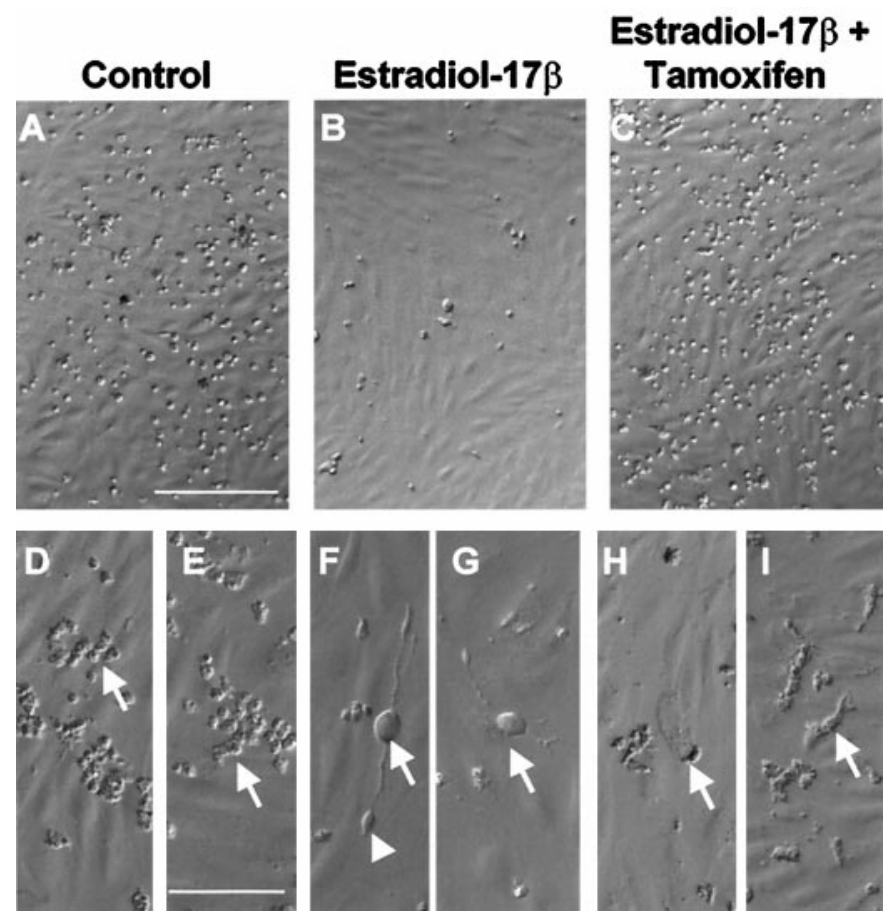

Figure 5. Low- and high-magnification photomicrographs of living cells (using Hoffman modulation) show that in control cultures $(A, D, E)$ CHB50 cells die when cultured at $39^{\circ} \mathrm{C}$ for $48 \mathrm{hr}$. Dead cells appear condensed and pyknotic $(D, E$, arrow) Exposure to estradiol-17 $\beta(B, F, G)$ prevents the temperature-dependent induction of cell death. Additionally, estrogen-treated cells differentiate $(F, G$, arrows) and express elongated processes and growth cones ( $F$, arrowhead). Concurrent exposure to tamoxifen $(C, H, I)$, attenuates estrogen induction of survival. Tamoxifentreated cells also exhibit a granular cytoplasm $(H, I$, arrow $)$. Scale bars: $A$, $35 \mu \mathrm{m}$ (applies to $A-C) ; E, 70 \mu \mathrm{m}$ (applies to $D-I$ ).

cause the effects of BDNF, NT-3, and NT-4 on cell density were similar, subsequent experiments used a cocktail of these neurotrophins to serve as a comparison to estradiol-17 $\beta$.

\section{Regulation of apoptosis at $39^{\circ} \mathrm{C}$}

To determine if changes in cell number were caused by the regulation of apoptosis, $\mathrm{CHB} 50$ cells were maintained at $39^{\circ} \mathrm{C}$ for 48 hr. Apoptotic cells were identified by labeling fragmented nuclear DNA. Analysis of the density of TUNEL-positive nuclei 

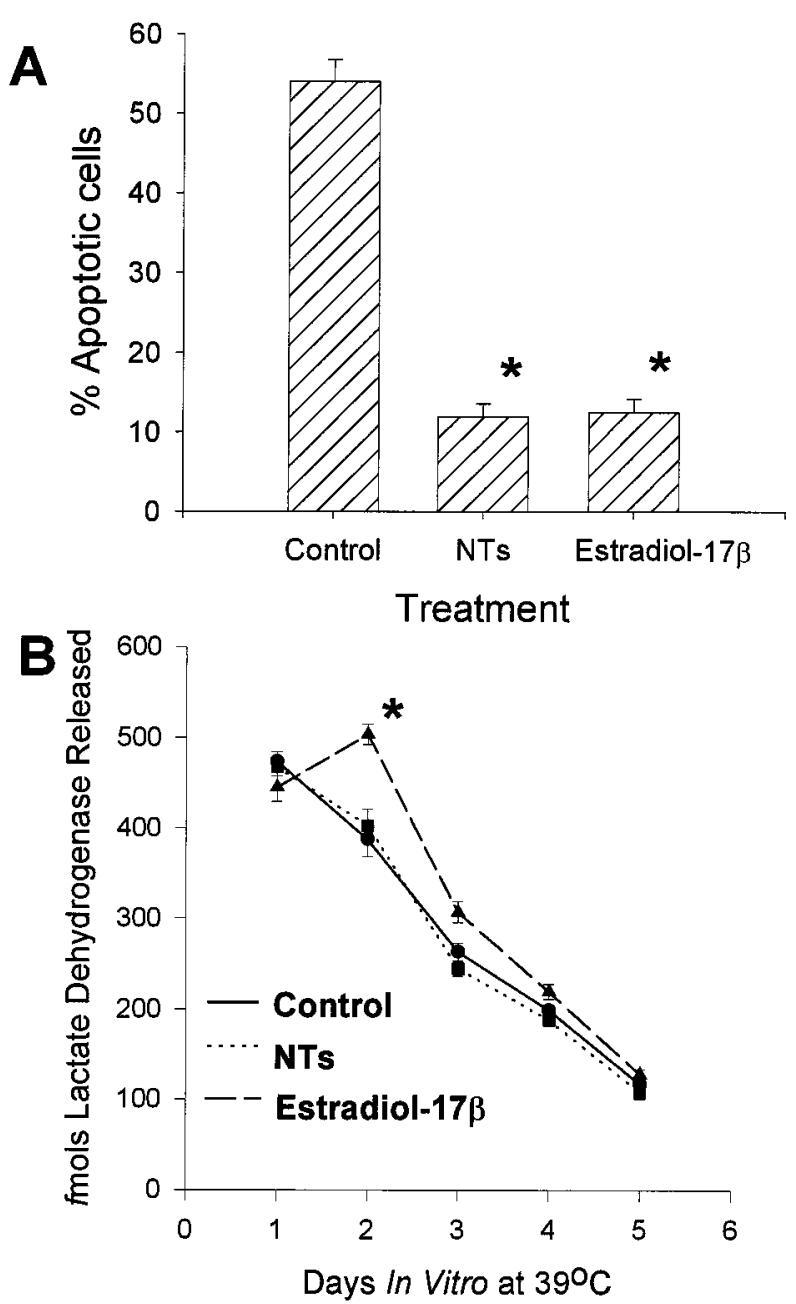

Figure 6. A, Change in percentage of apoptotic cells relative to the total number of cells after treatment with a neurotrophin cocktail $(\mathrm{NTs}=$ BDNF + NT-3 + NT-4) or estrogen for $48 \mathrm{hr}$ at $39^{\circ} \mathrm{C}$. B, Changes in necrotic cell lysis (lactate dehydrogenase released) after treatment with estrogen or the neurotrophin cocktail (NTs) for $5 \mathrm{~d}$ at $39^{\circ} \mathrm{C}$. Asterisk indicates statistically significant difference relative to controls.

indicated that estradiol-17 $\beta$ (at $2 \mathrm{~nm}$ ), and the neurotrophin cocktail (BDNF, NT-3, and NT-4 at $50 \mathrm{ng} / \mathrm{ml}$ each) led to a significant fivefold reduction in the percentage of cells undergoing apoptosis (Fig. 6A).

\section{Regulation of necrosis at $39^{\circ} \mathrm{C}$}

$\mathrm{LDH}$ released into culture medium was used as an indicator of cell membrane lysis and hence a marker for necrosis. Twenty four hours after transfer of CHB50 cells to $39^{\circ} \mathrm{C}$, the mean levels of released $\mathrm{LDH}$ ranged from 445 to $474 \mathrm{fmol}$ for the different treatment conditions (Fig. 6B). There was a significant temporal decline in $\mathrm{LDH}$ released, so that at the end of $5 \mathrm{~d}$, mean levels ranged from 108 to 144 fmol for the different treatment conditions. However, estradiol-17 $\beta$ led to a significant but transient increase in released $\mathrm{LDH}$ on the second day at $39^{\circ} \mathrm{C}$, although levels returned back to control values subsequently. In contrast, the neurotrophins did not lead to a change in released $\mathrm{LDH}$ compared with controls.

\section{Regulation of cell proliferation at $39^{\circ} \mathrm{C}$}

BrdU incorporation was used as a measure of cell proliferation. $\mathrm{CHB} 50$ cells cultured at $39^{\circ} \mathrm{C}$ were provided a daily dose of $\mathrm{BrdU}$

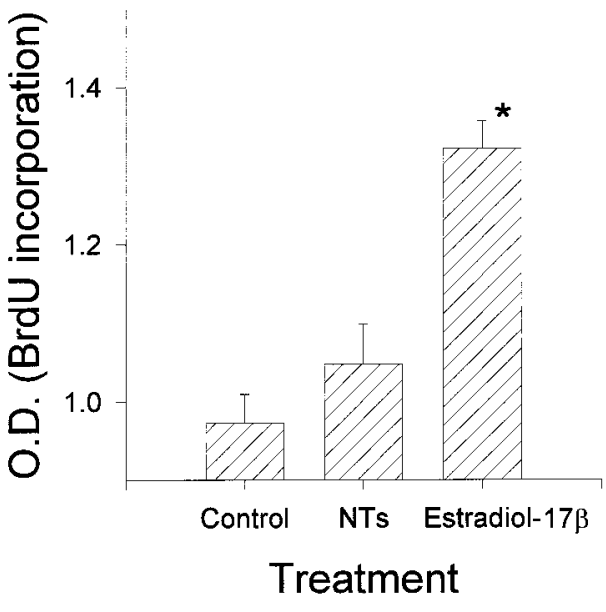

Figure 7. Changes in cell proliferation (BrdU incorporation) after treatment with the neurotrophin cocktail $(N T s)$ or estrogen for $5 \mathrm{~d}$ at $39^{\circ} \mathrm{C}$. ELISA assays indicated that estradiol- $17 \beta$ induced a significant (indicated by an asterisk) increase in BrdU incorporation relative to controls or NTs.

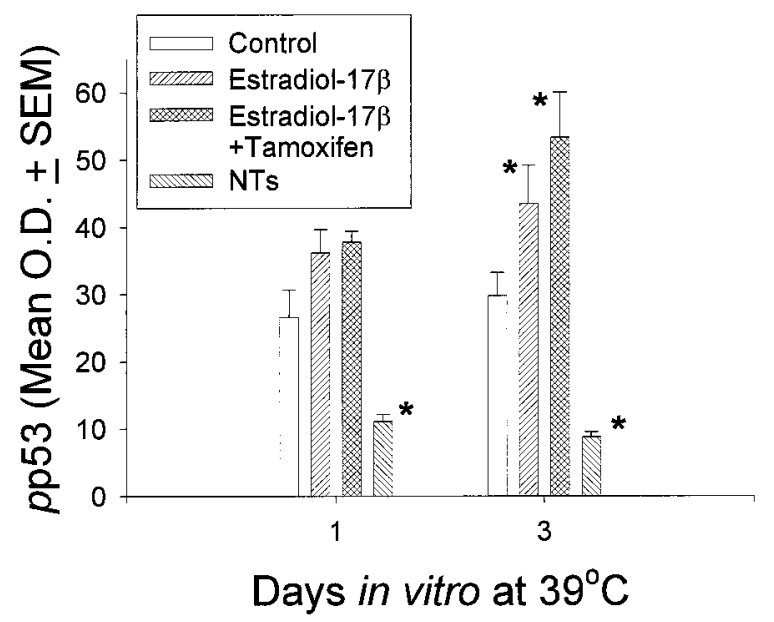

Figure 8. Densitometric analysis of $p \mathrm{p} 53$ (phosphoserine-392-p53) expression at $39^{\circ} \mathrm{C}$, in control cultures, or after treatment with estradiol- $17 \beta$ alone and concurrently with the antagonist tamoxifen, or neurotrophin $(N T s)$, for 1-3 d. Asterisk indicates statistical significance relative to time-matched controls.

for $5 \mathrm{~d}$. The analysis of BrdU incorporation indicated that estradiol-17 $\beta$ led to a significant increase in cell proliferation (Fig. 7). In contrast, cultures exposed to the neurotrophin cocktail were no different from controls.

\section{Regulation of pp53 and p53-dependent proteins Bax, p21/Waf1, and MDM2 at $39^{\circ} \mathrm{C}$}

Estrogen led to a significant increase in pp53 expression at $72 \mathrm{hr}$. This increase was not reversed by concurrent exposure to tamoxifen (Fig. 8). In contrast, the neurotrophins led to a significant decrease in $p$ p53 expression. The neurotrophins however, did not alter expression of any of the p53-dependent proteins (Fig. 9A$C)$. In contrast, estrogen led to a significant decrease in Bax expression (Fig. 9A) while inducing an opposite and significant increase in the expression of p21/Waf1 (Fig. 9B). Furthermore, estrogen regulated MDM2 (p85) in a biphasic manner (Fig. 9C). After $24 \mathrm{hr}$ of incubation at $39^{\circ} \mathrm{C}$, there was an initial and statistically significant estrogen-induced increase in MDM2 (p85), compared with control cultures. However, at the end of $5 \mathrm{~d}$, 

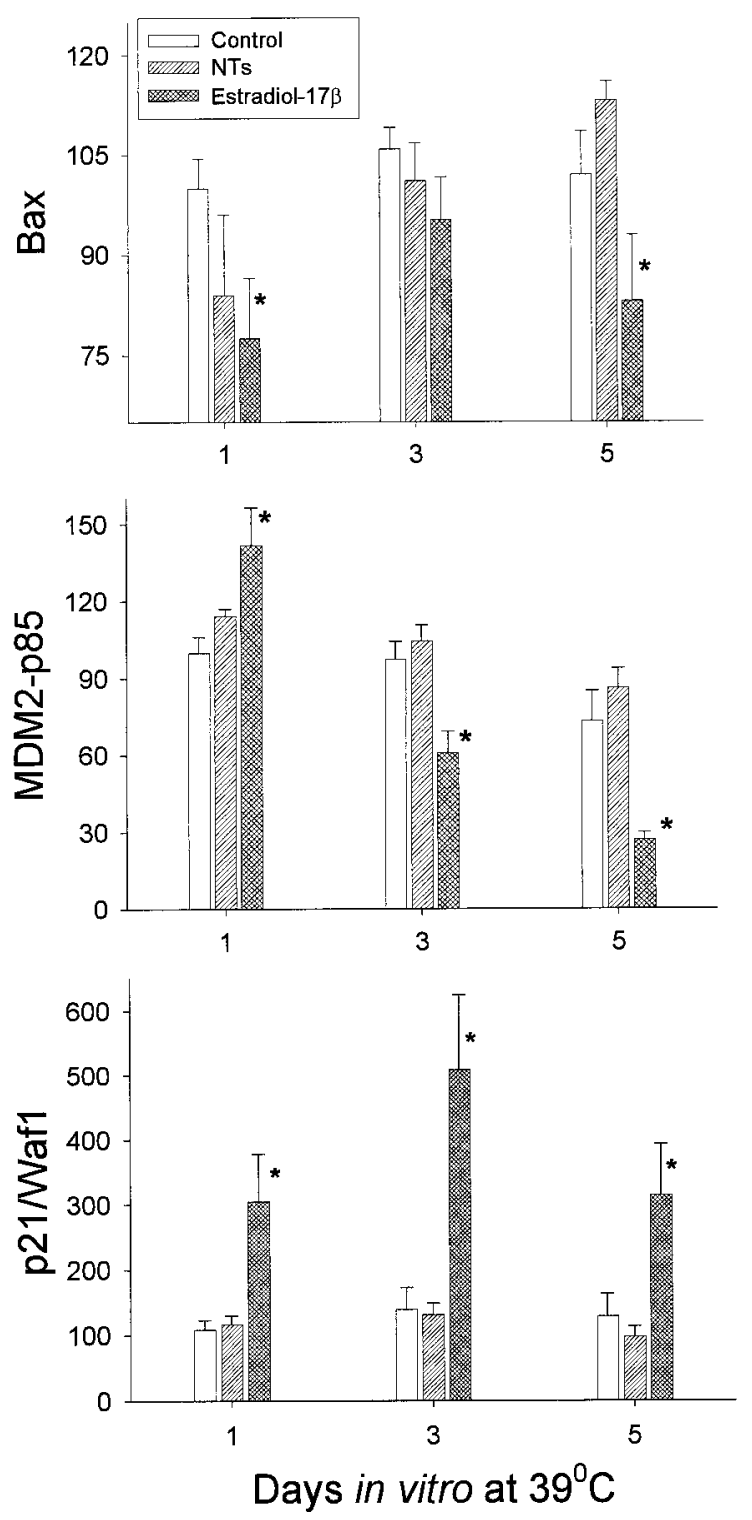

Figure 9. Densitometric analysis of Bax, MDM2-p85, and p21/Waf1 expression at $39^{\circ} \mathrm{C}$ in control cultures, or after treatment with estradiol $17 \beta$, or neurotrophin cocktail, for 1-5 d. Asterisk indicates statistical significance relative to time-matched controls.

MDM2 levels in estrogen-treated cultures were significantly decreased relative to control levels.

\section{Expression of neural phenotypic markers at $39^{\circ} \mathrm{C}$ and relationship to mitosis and apoptosis}

$\mathrm{CHB} 50$ cells cultured at $33^{\circ} \mathrm{C}$ expressed some GFAP and nestin immunoreactivity (Table 1). At $39^{\circ} \mathrm{C}$, control cultures maintained for $5 \mathrm{~d}$ in vitro expressed nestin (Fig. 10A) as well as neurofilament (Fig. 10D,E) and GFAP (Fig. 11iA,iB) immunoreactivity, but were negative for oligodendrocytic markers (Fig. 11iiA, iiiA). Estrogen-treated cultures also expressed neuroepithelial (Fig. $10 B$ ), neuronal (Fig. $10 F, G$ ), and astroglial (Fig. 11iC,iD) markers as did neurotrophin-treated cultures (Figs. 10C, H,I, 11iE, $i F$ ). In contrast to the neurotrophin-treated cultures that expressed both oligodendrocytic markers (CNPase and galactocerebroside; Fig. 11iiC, iiiC), estrogen-treated cultures only expressed one oli- godendrocytic marker (galactocerebroside; Fig. 11, compare iiB, iiiB).

In control cultures, apoptotic nuclei (condensed and fragmented nuclei stained by bis-benzamide) were observed in cells immunoreactive for both neurofilament markers (Fig. 10D) and for GFAP (Fig. 11iA). However, virtually no apoptotic nuclei colocalized to nestin-immunoreactive cells. In estrogen-treated cultures, mitotic figures were observed in neurofilament (Fig. $10 F$, inset) and GFAP-immunoreactive cells (Fig. 11iC, inset) but not in cells immunoreactive for nestin or oligodendrocytic markers. No mitotic figures were observed in control or neurotrophintreated cultures.

GFAP-positive cells in control and estrogen-treated cultures exhibited an epitheliod morphology. In contrast, GFAP-positive cells in neurotrophin-treated cultures expressed both epitheliod and stellate-type morphologies. In control cultures, nonapoptotic neurofilament-positive neurons generally expressed an epitheliod morphology. Both estrogen and neurotrophin treatments led to a modest appearance of dendritic processes. In comparison, to the estrogen and neurotrophin treatments, retinoic acid (1.0 nM for $5 \mathrm{~d}$ ) led to a dramatic increase in dendritic length (Fig. 12) and promoted the differentiation of pyramidal-type neuronal morphology.

\section{DISCUSSION}

Cerebral cortical development requires orderly transitions between neurogenesis and differentiation. Neurogenesis also results in overproduction of neurons that are selectively targeted for apoptosis. In these experiments, we conditionally immortalized (Almazan and McKay, 1992; Yanai and Obinata, 1994; Taher et al., 1995; Eves et al., 1996) neural precursors from embryonic rat cerebral cortex, to contrast estrogen and neurotrophin regulation of p53-dependent cortical differentiation and death.

The large $\mathrm{T}$ antigen promotes mammalian cell cycle by inhibiting checkpoint transcription factors like p53 (for review, see Levine, 1997). Consequently, the $T s / U 19$ large T antigen mutation permits synchronization of differentiation, by conditionally regulating p53-dependent mechanisms. At the nonpermissive temperature $\left(39^{\circ} \mathrm{C}\right)$, large $\mathrm{T}$ antigen expression ceases and substantial cell death occurs, that is partly caused by apoptosis. At this temperature, we also observed induction of $p$ p53 and p53dependent proteins such as the suicide protein Bax, the p53inhibitor, MDM2, and the cell-cycle arrest protein, P21/Waf1.

In the p53-activated condition, estrogen induced a dose-related increase in cortical cell density, compared to controls. These results were mimicked by BDNF, NT-3, and NT-4, but not NGF, suggesting that NGF is not a major survival factor in early cortical development. CHB50 cells express $\mathrm{ER} \alpha$ as well as TrkB and TrkC, and estrogen prevention of cell death was attenuated by the antagonist tamoxifen. Furthermore, estrogen as well as a cocktail of BDNF, NT-3, and NT-4 led to a marked reduction in apoptosis as compared with controls, suggesting that treatmentmediated increase in cell number was, in part, caused by cell suicide reduction.

Although estrogen and the neurotrophins effectively prevented apoptosis, these agents did not decrease naturally occurring necrotic cell death, measured by $\mathrm{LDH}$ release into culture media. In fact, estrogen specifically promoted a transient increase in $\mathrm{LDH}$ release, suggesting that this hormone may promote necrosis in some neural cells. One possible explanation for the transient induction of LDH release is that estrogen stimulated glutaminergic neurotransmission and consequent cytotoxicity. Glutamate- 
Table 1. Conditional and treatment dependent expression of neural markers in immortalized CHB50 cerebral cortical cells

\begin{tabular}{|c|c|c|c|c|}
\hline \multirow[b]{3}{*}{ Antigen Treatment } & \multicolumn{4}{|c|}{ Culture temperature } \\
\hline & \multirow[t]{2}{*}{$33^{\circ} \mathrm{C}$} & \multicolumn{3}{|c|}{$39^{\circ} \mathrm{C}$} \\
\hline & & Control & estradiol-17 $\beta$ & NTs $($ BDNF + NT3 + NT4) \\
\hline \multicolumn{5}{|l|}{ Neuroepitheloid markers } \\
\hline Nestin & $+/-$ & + & + & + \\
\hline \multicolumn{5}{|l|}{ Neuronal markers } \\
\hline Neurofilament $(150+200)$ & - & $+1-$ & + & + \\
\hline \multicolumn{5}{|l|}{ Astrocytic markers } \\
\hline GFAP & + & + & + & + \\
\hline \multicolumn{5}{|l|}{ Oligodendrocytic markers } \\
\hline CNPase & - & - & - & + \\
\hline Galactocerebroside & - & - & + & + \\
\hline
\end{tabular}

Conditionally immortalized cerebral cortical-derived neuroblasts (CHB50 cells) were cultured at the permissive temperature for large $\mathrm{T}$ antigen expression $\left(33^{\circ} \mathrm{C}\right)$ or for $5 \mathrm{~d}$ at the nonpermissive temperature $\left(39^{\circ} \mathrm{C}\right)$ in the presence of control medium, estradiol-17 $\beta$, or neurotrophin cocktail (NTs). Cultures were tested for the expression of markers for neural stem cell, neuronal, and glial markers using fluorescence immunohistochemistry. -, No immunoreactive cells observed; +/-, immunoreactive cells present in some fields; + , immunoreactive cells observed in all fields.
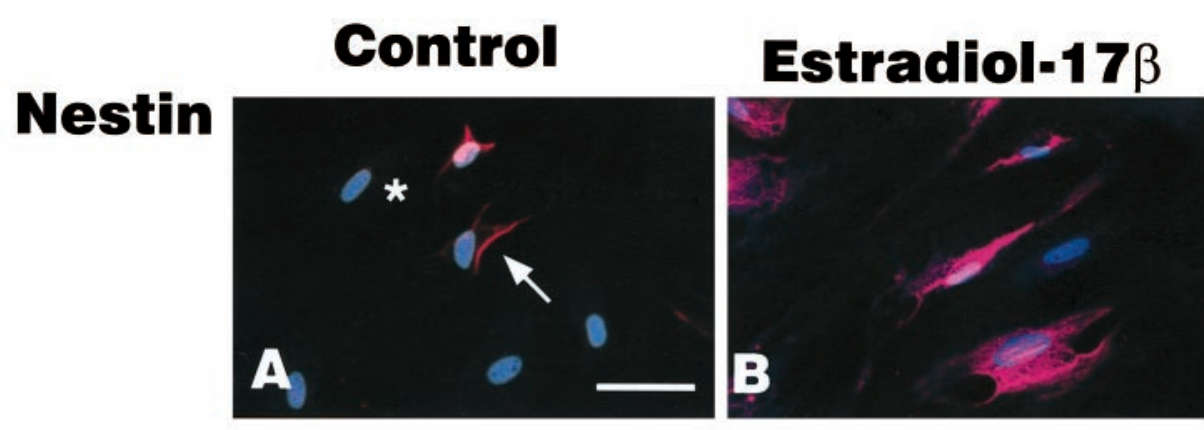

\section{Neurotrophins}
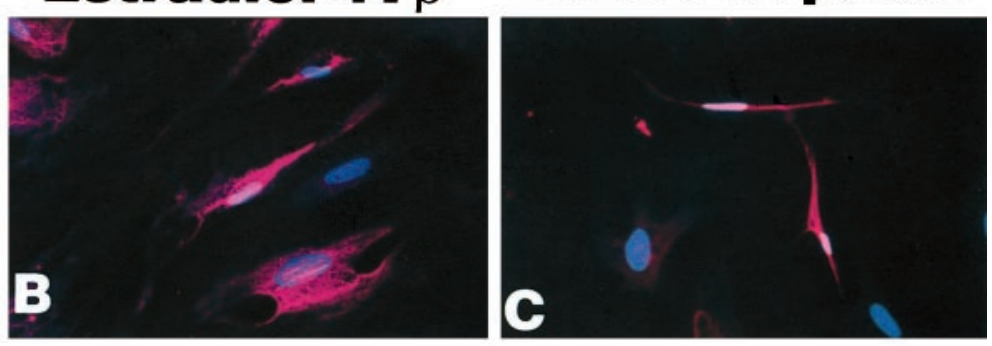

\section{NF150+ 200}
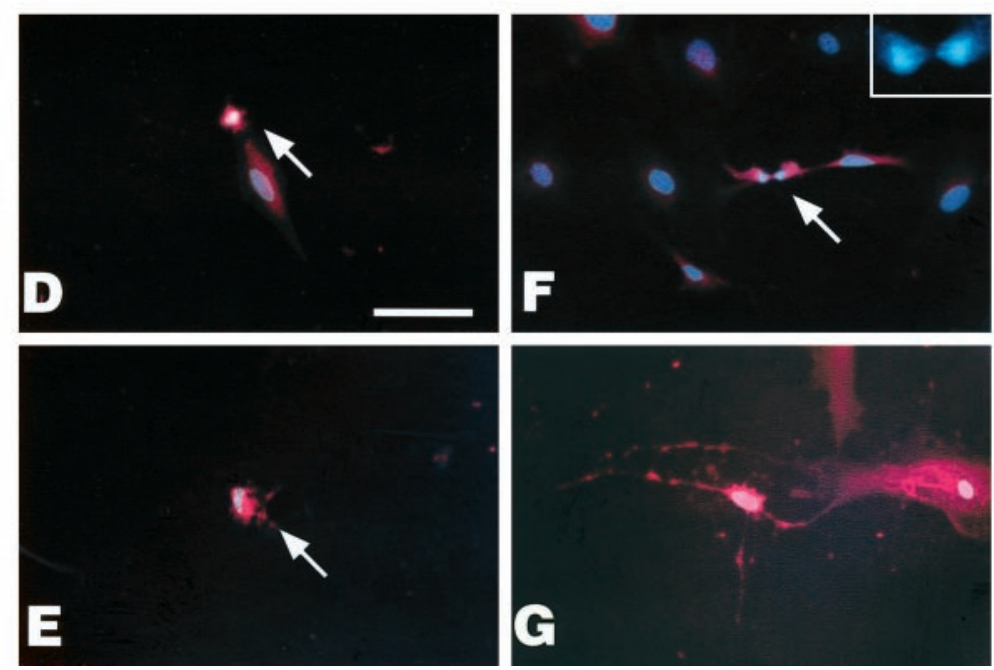
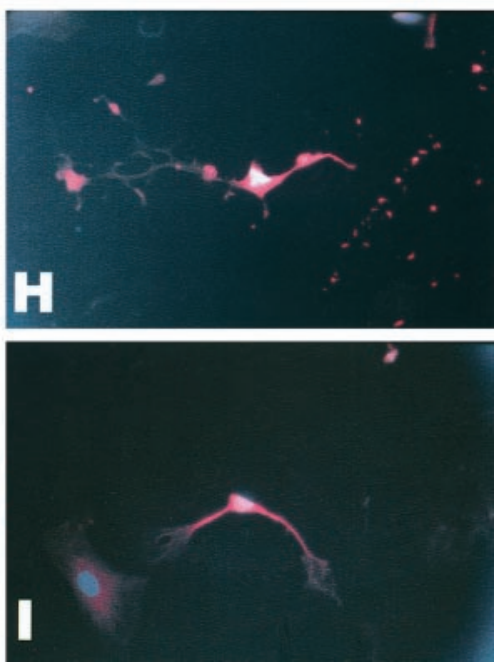

Figure 10. A-C, Expression of the neuroepithelial stem cell marker Nestin (red) and nuclear counterstain (Hoechst dye \#33258, blue-white) in cultures maintained at $39^{\circ} \mathrm{C}$ for $5 \mathrm{~d}$ in the presence of $(A)$ control medium (arrow indicates stained cell, asterisk indicates unstained cell), $(B)$ estrogen, and $(C)$ neurotrophins. $D-I$, Expression of neuronal marker [neurofilaments (NF), 150 and $200 \mathrm{kDa}$ ] in cultures maintained at $39^{\circ} \mathrm{C}$ for $5 \mathrm{~d}$ in the presence of $(D, E)$ control medium; arrows indicate immunoreactivity in apoptotic cells, $(F, G)$ estrogen, [arrow and inset in $F$ indicates immunoreactivity in mitotic cell undergoing cytokinesis (late anaphase/early telophase)], and (H, I) neurotrophin cocktail. Scale bar, $70 \mu \mathrm{m}$.

mediated cytotoxicity has been previously reported, after neurotrophin treatment of cultured cortical cells (Koh et al., 1995). Although estrogen promotes aspects of glutamate neurotransmission (Woolley and McEwen, 1994; Gazzaley et al., 1996; Woolley et al., 1997) and seizure induction (Morrell, 1992), it prevents glutamate neurotoxicity (Behl et al., 1995; Chan et al., 1996; Singer et al., 1996). Therefore, the glutamate toxicity hypothesis is unlikely to be correct. The transient induction of necrosis may have resulted from induction of as-yet-unidentified mechanisms. Alternatively estrogen-dependent necrosis may represent an end 

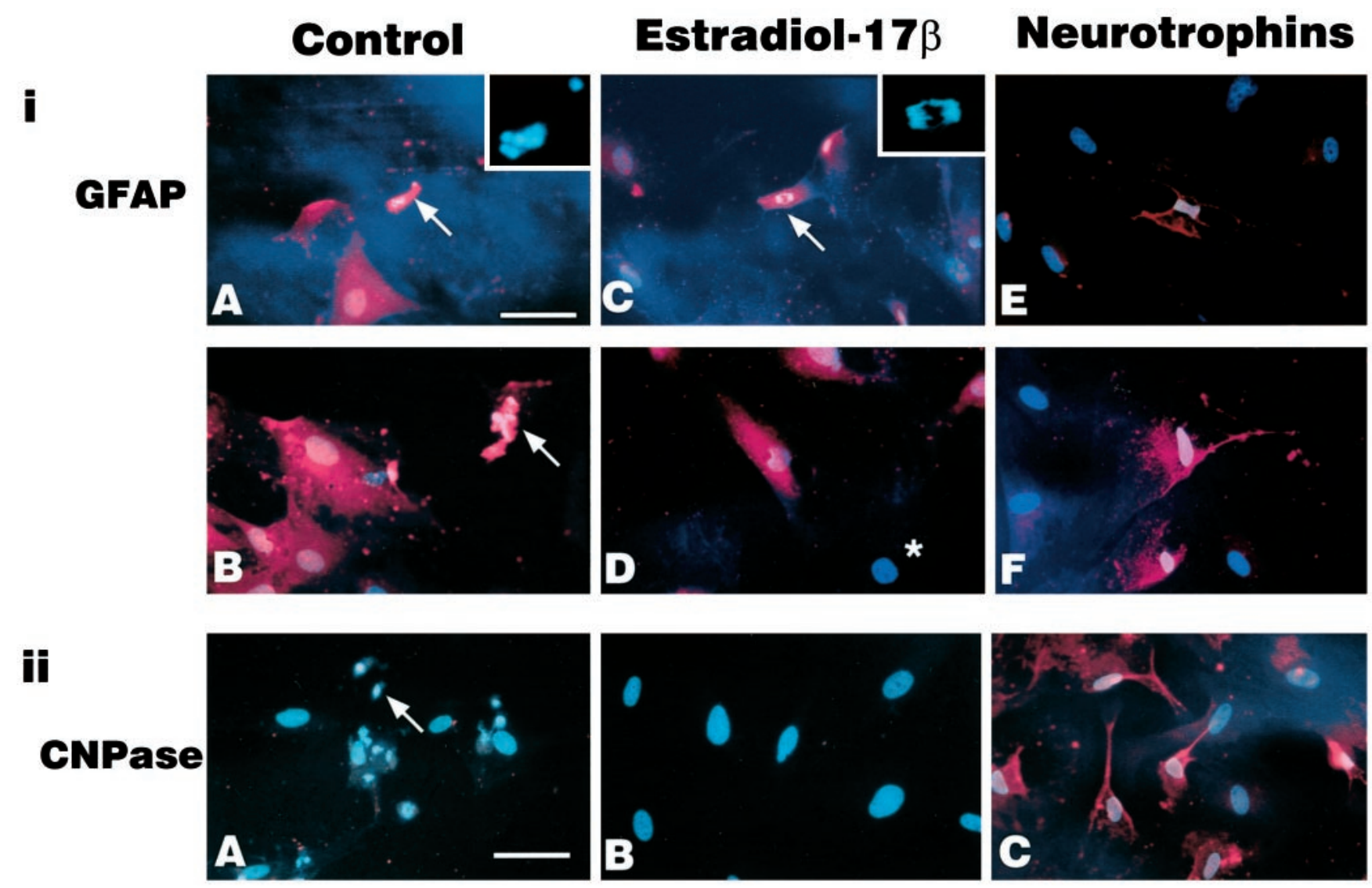

\section{ifi}

\section{Galacto- cerebroside}
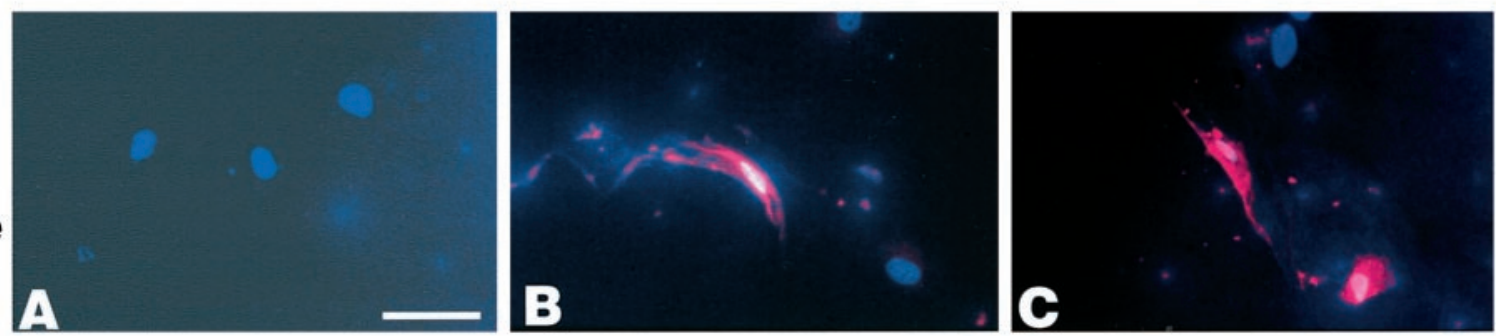

Figure 11. $i A-i F$, Expression of the astrocytic marker GFAP $(r e d)$ and nuclear counterstain (blue-white) in cultures maintained at $39^{\circ} \mathrm{C}$ for $5 \mathrm{~d}$ in the presence of $(i A, i B)$ control medium, (arrows indicate GFAP-positive apoptotic cells. Inset in $i A$ is a high magnification of the nuclear counterstain showing nuclear fragmentation characteristic of apoptosis), $(i C, i D)$ estrogen (arrow and inset show mitotic GFAP-positive cell in early anaphase, asterisk indicates unstained cell), and ( $i E, F)$ neurotrophin cocktail. $i i A-i i C$, Expression of oligodendrocytic marker CNPase was absent in (iiA) control (arrow indicates apoptotic cell) and ( $i i B)$ estrogen-treated cultures, but present in $(i i C)$ neurotrophin-treated cultures. $i i i A-C$, Expression of the oligodendrocytic marker galactocerebroside was not observed in (iiiA) control cultures, but was present in cultures treated with (iiiB) estrogen and (iiiC) neurotrophins. Scale bar, $70 \mu \mathrm{m}$.

stage of early and rapid apoptosis. Such necrosis also occurs in vitro, as a late end stage of tumor necrosis factor- $\alpha$-induced apoptosis (Leist et al., 1994). Thus, estrogen may induce one population of cortical cells to undergo apoptosis, while protecting other cohorts.

Estrogen has divergent, tissue-specific actions on survival and death in other hormone targets as well. It promotes cell survival in breast epithelium (Kyprianou et al., 1991; Wang and Phang, 1995), uterine endometrium (Nawaz et al., 1987; Rotello et al., 1989), and osteocytes (Tomkinson et al., 1997) while inducing apoptosis in osteoclasts (Hughes et al., 1996; Kameda et al., 1997), erythroid cells (Blobel and Orkin, 1996), prostate (Landstrom et al., 1996; Robertson et al., 1996), and testis (Nonclercq et al., 1996). Similarly, estrogen has divergent survival and death actions in neural tissues. Estrogen metabolites induce apoptosis in neuroblastoma cells (Nakagawa-Yagi et al., 1996), whereas estrogen promotes survival in hypothalamic cell lines (Rasmussen et al., 1990). Estrogen also inhibits apoptosis in the sexually dimorphic nucleus of the preoptic area while inducing apoptosis in an adjacent hypothalamic nucleus, the anteroventral periventricular nucleus of the preoptic area (Arai et al., 1996). These data collectively support the hypothesis that estrogen may induce both survival and cell-death functions in the developing cerebral cortex.

In contrast to the neurotrophins, estrogen promoted cell proliferation, thereby contributing partly to an increase in cell number. At the differentiation temperature, estrogen increased BrdU incorporation, and estrogen-treated cultures exhibited mitotic figures. Furthermore, mitosis was observed in cells that expressed mature neuronal and astroglial but not neuroepitheliod markers, 

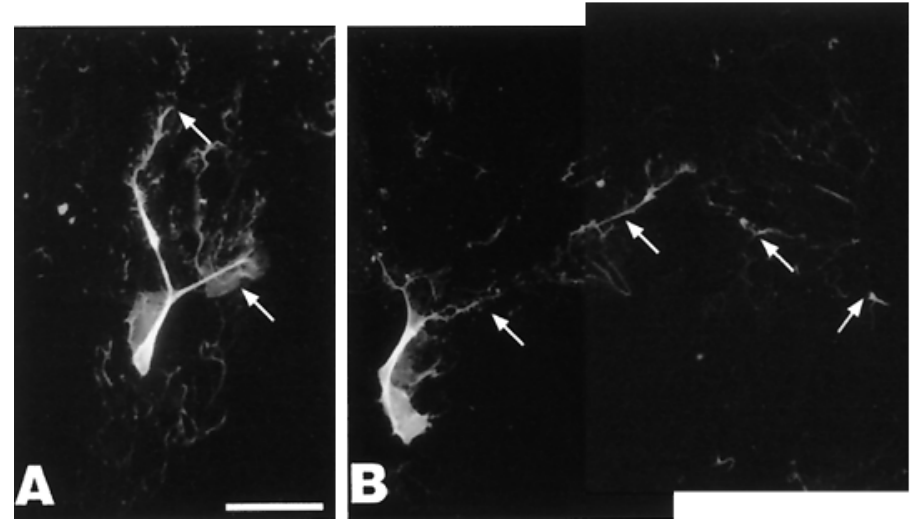

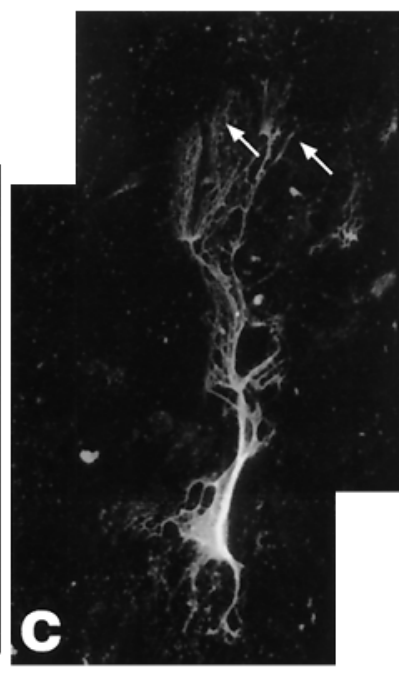

Figure 12. $A-C$, Expression of neuronal markers (neurofilament 150 and 200 $\mathrm{kDa}$ ) in CHB50 cultures maintained at $39^{\circ} \mathrm{C}$ for $5 \mathrm{~d}$ in the presence of retinoic acid. Arrows show extensive dendritic fields of neurons in this treatment group. Magnification is identical to photomicrographs in Figure $10 D-I$. Scale bar, $70 \mu \mathrm{m}$. suggesting that estrogen may promote cell cycle reentry in cells that were committed to neural differentiation. Peripheral nervous system cells continue to proliferate after commitment to specific catecholaminergic differentiation fates, and postcommitment proliferation is required for final phenotypic differentiation (Rothman et al., 1980). Thus, estrogen stimulation of cell cycle in committed neuronal and astroglial cells may be important for cell fate commitment. Alternatively, estrogen-mediated reduction in apoptosis and enhancement of cell proliferation may be related phenomena. For example, we have recently observed estrogen induction of cell cycle proteins in the presence of death signals (Z. F. Cheema and R. C. Miranda, unpublished observations). Thus, estrogen may prevent cell suicide by permitting cells to reinitiate cell cycle progression.

Estrogen induced $p$ p53 expression that was not attenuated by the antagonist tamoxifen. The differential effect of tamoxifen on cell death and p53 activation is consistent with its role as a context-dependent antagonist (Mathews and Arnold, 1991a,b), particularly in the case of estrogen receptor activation of nonconsensus transcription elements [e.g., AP-1 (Paech et al., 1997)]. Estrogen induction of p53 may, therefore, be mediated by mechanisms other than the activation of consensus estrogen response elements, including perhaps, activation of antagonist-insensitive protein phosphorylation mechanisms (Singh et al., 1999). Estrogen induction of p53 activation was accompanied by a differential regulation of $\mathrm{p} 53$-dependent proteins, suggesting that $\mathrm{p} 53$ transcriptional activation of Bax, p21/Waf1, and MDM2 is uncoupled by estrogen. Such uncoupling of p53 mechanisms has also been observed in osteoblasts, after administration of vitamin-D3, an activator of a member of the steroid hormone receptor superfamily (Matsumoto et al., 1998).

The estrogen-induced decrease in Bax is consistent with an anti-apoptotic role for estrogen in cortical development. However, estrogen induced the cell cycle arrest protein, P21/Waf1, suggesting that estrogen may cause cells to exit cell cycle and differentiate. This result is consistent with our observations that estrogen supports differentiation of neuronal and glial phenotypes, but is not consistent with observations that estrogen additionally induced cell proliferation. However, estrogen also induced a rapid increase in MDM2 expression at $24 \mathrm{hr}$, compared with controls, providing a mechanism for cell cycle reinitiation. MDM2 is a p53-induced protein that in turn, inhibits p53 func- tion (Lozano and de Oca Luna, 1998). $\beta$ FGF, a mitogenic factor, induces MDM2 independently of p53 (Shaulian et al., 1997), suggesting that estrogen induction of MDM2 may be p53independent as well. MDM2 in turn subjects p53 and other intrinsic differentiation signals, including the neural cell fate protein numb (Juven-Gershon et al., 1998), to ubiquitin-mediated degradation (Lozano and de Oca Luna, 1998), thereby inducing reentry into cell cycle. However, estrogen induced a subsequent decline in MDM2 expression while simultaneously suppressing Bax and inducing p21/Waf1, suggesting that estrogen may lead to a delayed induction of p53-mediated differentiation while suppressing p53-mediated apoptosis. In contrast to estrogen, the neurotrophins decreased p53 activation, consistent with previous reports, that in promyelocytic leukemias, MAP kinase (a downstream element in the neurotrophin signal transduction cascade) activation, targets p53 for ubiquitin-mediated degradation (Song et al., 1999). However, neurotrophins did not alter expression of the p53-dependent proteins, suggesting that neurotrophin suppression of cell suicide and induction of differentiation in these cerebral cortical cells may occur by p53-independent mechanisms or mechanisms unrelated to the regulation of Bax and p21/Waf1.

Estrogen and the neurotrophins also differentially regulated the expression of neural phenotypes. Control CHB50 cells cultured at $39^{\circ} \mathrm{C}$ express the astrocytic marker GFAP, as well as nestin [a marker for CNS stem cells (Lendahl et al., 1990)], but not oligodendrocytic markers. These results are consistent with reports suggesting that neural stem cells retain pluripotency and are able to express multiple phenotypes after immortalization (Eves et al., 1992; Lundberg et al., 1997). In these control cultures, neuronal markers were found localized to apoptotic cells, implying that differentiation in the absence of appropriate cellular context or appropriate trophic support is associated with cell death induction, perhaps by Bax-dependent mechanisms. Although estrogen and the neurotrophins did support neuronal differentiation, estrogen-treated cells were less mature and quasiepitheliod compared with neurotrophin-treated cells. However, neither of these factors induced dendritic arborization, comparable to that observed with retinoic acid (activator of another member of the steroid hormone receptor family). Thus, a series of trophic signals may be required for complete neuronal differentiation.

Steroid hormone receptor and neurotrophin receptor-mediated differentiation signals may not be completely independent of each 
other. One possibility is that members of the steroid hormone receptor family may have overlapping differentiative roles in neurotrophin-sensitive targets. This hypothesis is supported by reports indicating that estrogen upregulates trkA (the NGF receptor) in PC12 cells (Sohrabji et al., 1994a), whereas retinoic acid induces the differentiation of these cells into a cholinergic phenotype (Matsuko et al., 1989). In general, there are substantial regulatory interactions between estrogen (Miranda and ToranAllerand, 1992; Toran-Allerand et al., 1992a; Miranda et al., 1993, 1996; Singh et al., 1994, 1995; Sohrabji et al., 1994a,b, 1995; McMillan et al., 1996), retinoic acid (Schiebe et al., 1992; Kaplan et al., 1993), and the neurotrophins. Finally, steroid hormones and the neurotrophins regulate similar differentiation-associated proteins such as GAP-43 (Federoff et al., 1988; Lustig et al., 1991; Shughrue and Dorsa, 1994). These data are collectively consistent with the notion that there are complex, multistep interactions between hormones and growth factors in the regulation of cell fate (for review, see Dickson and Lippman, 1987), including neurogenesis, survival, and differentiation, within the developing cerebral cortex.

\section{REFERENCES}

Almazan G, McKay R (1992) An oligodendrocyte precursor cell line from rat optic nerve. Brain Res 579:234-245.

Arai Y, Sekine Y, Murakami S (1996) Estrogen and apoptosis in the developing sexually dimorphic preoptic area in female rats. Neurosci Res 25:403-407.

Bamji SX, Majdan M, Pozniak CD, Belliveau DJ, Aloyz R, Kohn J, Causing CG, Miller FD (1998) The p75 neurotrophin receptor mediates neuronal apoptosis and is essential for naturally occurring sympathetic neuron death. J Cell Biol 140:911-923.

Barrett G, Bartlett P (1994) The p75 nerve growth factor receptor mediates survival or death depending on the stage of sensory neuron development. Proc Natl Acad Sci USA 91:6501-6505.

Bayer SA, Altman J (1995) Neurogenesis and neuronal migration. In: The rat nervous system (Paxinos G, ed), pp 1041-1078. San Diego: Academic.

Beato M, Herrlich P, Schutz G (1995) Steroid hormone receptors: Many actors in search of a plot. Cell 83:851-857.

Behl C, Widmann M, Trapp T, Holsboer F (1995) $17-\beta$ estradiol protects neurons from oxidative stress-induced cell death in vitro. Biochem Biophys Res Commun 216:473-482.

Blaschke A, Staley K, Chun J (1996) Widespread programmed cell death in proliferative and postmitotic regions of the fetal cerebral cortex. Development 122:1165-1174.

Blaschke A, Weiner J, Chun J (1998) Programmed cell death is a universal feature of embryonic and postnatal neuroproliferative regions throughout the central nervous system. J Comp Neurol 396:39-50.

Blobel GA, Orkin SH (1996) Estrogen-induced apoptosis by inhibition of the erythroid transcription factor GATA-1. Mol Cell Biol 16:1687-1694.

Brandenberger AW, Tee MK, Lee Jy, Jaffe RB (1997) Tissue distribution of estrogen receptors $\alpha($ ER- $\alpha)$ and $\beta$ (ER- $\beta)$ mRNA in the midgestational human fetus. J Clin Endocrinol Metab 82:3509-3512.

Chan RS, Huey ED, Maecker HL, Cortopassi KM, Howard SA, Iyer AM, McIntosh LJ, Ajilore OA, Brooke SM, Sapolsky RM (1996) Endocrine modulators of necrotic cell death. Brain Pathol 6:481-491.

Chao M (1992) Growth factor signaling: where is the specificity? Cell 68:995-997.

Chao MV, Hempstead B (1995) p75 and Trk: a two-receptor system. Trends Neurosci 18:321-326.

Cheema ZF, Wade SB, Sata M, Walsh K, Sohrabji F, Miranda R (1999) Fas/Apo [apoptosis]-1 and associated proteins in the differentiating cerebral cortex: Induction of caspase-dependent cell death and activation of NF-kB. J Neurosci 19:1754-1770.

Chen L, Marechal V, Moreau J, Levine A, Chen J (1997) Proteolytic cleavage of the mdm2 oncoprotein during apoptosis. J Biol Chem 272:22966-22973.

Davies A, Wright EM (1995) Neurotrophin autocrine loops. Curr Biol 5:723-726.

Dickson RB, Lippman ME (1987) Estrogenic regulation of growth fac- tor and polypeptide growth factor secretion in human breast carcinoma. Endocrinol Rev 8:29-43.

Donovan M, Miranda R, Kraemer R, McCaffrey T, Tessarollo L, Mahadeo D, Kaplan D, Tsoulfas P, Parada L, Toran-Allerand D, Hajjar D, Hempstead B (1995) Neurotrophin and neurotrophin receptors in vascular smooth muscle cells: regulation of expression in response to injury. Am J Pathol 147:309-324.

Erhardt P, Tomaselli KJ, Cooper GM (1997) Identification of the MDM2 oncoprotein as a substrate for CPP32-like apoptotic proteases. J Biol Chem 272:15049-15052.

Eves EM, Tucker MS, Roback JD, Downen M, Rosner MR, Wainer BH (1992) Immortal rat hippocampal cell lines exhibit neuronal and glial lineages and neurotrophin gene expression. Proc Natl Acad Sci USA 89:4373-4377.

Eves EM, Boise LH, Thompson CB, Wagner A, Hay N, Rosner M (1996) Apoptosis induced by differentiation or serum deprivation in an immortalized central nervous system neuronal cell line. J Neurochem 67:1908-1920.

Federoff HJ, Grabczyk E, Fishman MC (1988) Dual regulation of GAP-43 gene expression by NGF and glucocorticoids. J Biol Chem 263:19290-19295.

Ferrer I, Bernet E, Soriano E, DelRio T, Fonseca M (1990) Naturally occurring cell death in the cerebral cortex of the rat and removal of dead cells by transitory phagocytes. Neuroscience 39:451-458.

Ferrer I, Soriano E, DelRio J, Alcantara S, Auladell C (1992) Cell death and removal in the cerebral cortex during development. Prog Neurobiol 39:1-43.

Filhol O, Baudier J, Chambaz E, Cochet C (1996) Casein kinase 2 inhibits the renaturation of complementary DNA strands mediated by p53 protein. Biochem J 316:331-335.

Finlay B, Slattery M (1983) Local differences in the amount of early cell death in neocortex predict adult local specializations. Science 219:1349-1351.

Friedman WJ, McEwen BS, Toran-Allerand CD, Gerlach JL (1983) Perinatal development of hypothalamic and cortical estrogen receptors in mouse brain: methodological aspects. Brain Res Dev Brain Res 11:19-27.

Gazzaley A, Weiland NG, McEwen BS, Morrison JH (1996) Differential regulation of NMDAR1 mRNA and protein by estradiol in the rat hippocampus. J Neurosci 16:6830-6838.

Gerlach JL, McEwen BS, Toran-Allerand CD, Friedman WJ (1983) Perinatal development of estrogen receptors in mouse brain assessed by radioautography, nuclear isolation and receptor assay. Brain Res Dev Brain Res 11:7-18.

Hempstead BL, Martin-Zanca D, Kaplan DR, Parada LF, Chao MV (1991) High affinity of NGF binding requires the co-expression of the trk proto-oncogene and the low affinity receptor. Nature 350:678-683.

Hoffmann R, Craik D, Pierens G, Bolger R, Otvos LJ (1998) Phosphorylation of the $\mathrm{C}$-terminal sites of human $\mathrm{p} 53$ reduces non-sequencespecific DNA binding as modeled with synthetic peptides. Biochemistry 37:13755-13764.

Hughes DE, Dai A, Tiffee JC, Li HH, Mundy GR, Boyce BF (1996) Estrogen promotes apoptosis of murine osteoclasts mediated by TGF-b. Nat Med 2:1132-1136.

Juven-Gershon T, Shifman O, Unger T, Elkekes A, Haupt Y, Oren M (1998) The $\mathrm{mdm} 2$ oncoprotein interacts with the cell fate regulator numb. Mol Cell Biol 18:3974-3982.

Kameda T, Mano H, Yuasa T, Mori Y, Miyazawa K, Shiokawa M, Nakamaru Y, Hiroi E, Hiura K, Kameda A, Yang NN, Hakeda Y, Kumegawa M (1997) Estrogen inhibits bone resorption by directly inducing apoptosis of the bone-resorbing osteoclasts. J Exp Med 186:489-495.

Kaplan DR, Matsumoto K, Lucareli E, Theile CJ (1993) Induction of trkB by retinoic acid mediates biological responsiveness to BDNF and differentiation of human neuroblastoma cells. Neuron 11:321-331.

Koh J, Gwag B, Lobner D, Choi D (1995) Potentiated necrosis of cultured cortical neurons by neurotrophins. Science 268:573-575.

Kuiper G, Enmark E, Pelto-Huikko M, Nilsson S, Gustafsson J-A (1996) Cloning of a novel estrogen receptor expressed in rat prostate and ovary. Proc Natl Acad Sci USA 93:5925-5930.

Kyprianou N, English HF, Davidson NE, Isaacs JT (1991) Programmed cell death during regression of the human MCF-7 human breast cancer following estrogen ablation. Cancer Res 51:162-166.

Landstrom M, Eklov S, Colosetti P, Nilsson S, Damber J-E, Bergh A, Funa K (1996) Estrogen induces apoptosis in rat prostatic adenocar- 
cinoma: association with an increased expression of TGF-b1 and its type-I and type-II receptors. Int J Cancer 67:573-579.

Leist M, Gantner F, Bohlinger I, Germann P, Tiegs G, Wendel A (1994) Murine hepatocyte apoptosis induced in vitro and in vivo by TNF-a requires transcriptional arrest. J Immunol 153:1778-1788.

Lendahl U, Zimmerman LB, McKay RDG (1990) CNS stem cells express a new class of intermediate filament protein. Cell 60:585-595.

Levine A (1997) p53, the cellular gatekeeper for growth and division. Cell 88:322-331.

Lozano G, de Oca Luna RM (1998) MDM2 function. Biochem Biophys Acta 1377:M55-M59.

Lundberg C, Martinez-Serrano A, Cattaneo E, McKay RD, Bjorklund A (1997) Survival, integration and differentiation of neural stem cell lines after transplantation to the adult rat striatum. Exp Neurol 145:342-360.

Lustig RH, Sudol M, Pfaff DW, Federoff HJ (1991) Estrogenic regulation and sex dimorphism of growth-associated protein $43 \mathrm{kDa}$ (GAP-43) mRNA in the rat. Mol Brain Res 1:125-132.

Ma ZQ, Spreafico E, Pollio G, Santagati S, Conti E, Cattaneo E, Maggi A (1993) Activated estrogen receptor mediates growth arrest and differentiation of a neuroblastoma cell line. Proc Natl Acad Sci USA 90:3740-3744.

Majdan M, Lachance C, Gloster A, Aloyz R, Zeindler C, Bamji SX, Bhakar A, Belliveau D, Fawcett J, Miller FD, Baker PA (1997) Transgenic mice expressing the intracellular domain of p75 neurotrophin receptor undergo neuronal apoptosis. J Neurosci 17:6988-6998.

Mangelsdorf D, Thummel C, Beato M, Herrlich P, Schutz G, Umesono K, Blumberg B, Kastner P, Mark M, Chambon P, Evans R (1995) Overview: the nuclear receptor superfamily: the second decade. Cell 83:835-839.

Mathews G, Arnold A (1991a) Tamoxifen's effects on the zebra finch song system are estrogenic, not antiestrogenic. J Neurobiol 22:957-969.

Mathews G, Arnold A (1991b) Tamoxifen fails to block estradiol accumulation, yet is weakly accumulated by the juvenile zebra finch anterior hypothalamus: an autoradiographic study. J Neurobiol 22:970-975.

Matsuko I, Mizuno N, Kurihara K (1989) Cholinergic differentiation of clonal rat pheochromocytoma cells (PC12) induced by retinoic acid: increase of choline acetyltransferase activity and decrease of tyrosine hydroxylase activity. Brain Res 502:53-60.

Matsumoto T, Sowa Y, Ohtani-Fujita N, Tamaki T, Takenaka T, Kuribayashi K, Sakai T (1998) p53-independent induction of Waf1/Cip1 is correlated with osteoblastic differentiation by vitamin D3. Cancer Lett 129:61-68.

McMillan P, Singer C, Dorsa D (1996) The effects of ovariectomy and estrogen replacement on trkA and cholineacetyltransferase mRNA expression in the basal forebrain of the adult female sprague-dawley rat. J Neurosci 16:1860-1865.

Miranda R, Toran-Allerand CD (1992) Developmental regulation of estrogen receptor mRNA in the rat cerebral cortex: a non-isotopic in situ hybridization study. Cereb Cortex 2:1-15.

Miranda R, Sohrabji F, Toran-Allerand CD (1993) Presumptive estrogen target neurons express mRNAs for both the neurothrophins and neurotrophin receptors: a basis for potential developmental interactions of estrogen with the neurotrophins. Mol Cell Neurosci 4:510-525.

Miranda R, Sohrabji F, Toran-Allerand CD (1994) Interactions of estrogen with the neurotrophins and their receptors during neural development. Horm Behav 28:367-375.

Miranda R, Sohrabji F, Singh M, Toran-Allerand CD (1996) Nerve growth factor (NGF) regulation of estrogen receptors in explant cultures of the developing forebrain. J Neurobiol 31:77-87.

Morrell MJ (1992) Hormones and epilepsy through the lifetime. Epilepsia 33:S49-S61.

Mosselman S, Polman J, Dijkema R (1996) ER $\beta$ : identification and characterization of a novel human estrogen receptor. FEBS Lett 392:49-53.

Nakagawa-Yagi Y, Ogane N, Inoki Y, Kitoh N (1996) The endogenous estrogen metabolite 2-methoxyestradiol induces apoptotic neuronal cell death in vitro. Life Sci 58:1461-1467.

Nawaz S, Lynch MP, Galand P, Gerschenson LE (1987) Hormonal regulation of cell death in rabbit uterine epithelium. Am J Pathol 127:51-59.

Nonclercq D, Reverse D, Toubeau G, Beckers JF, Sulon J, Laurent G, Zanen J, Heuson-Stiennon JA (1996) In situ demonstration of germinal cell apoptosis during diethylstilbestrol-induced testis regression in adult male syrian hamsters. Biol Reprod 55:1369-1376.

Noraberg A, Gramsbergen J, Fonnum F, Zimmer J (1998) Trimethyltin
(TMT) neurotoxicity in organotypic rat hippocampal slice cultures. Brain Res 783:305-315.

Nordeen EJ, Nordeen KW (1989) Estrogen stimulates the incorporation of new neurons into the avian song nuclei during adolescence. Dev Brain Res 49:27-32.

Olson DC, Marechal V, Momand J, Chen J, Romocki C, Levine A (1993) Identification and characterization of multiple mdm-2 proteins and mdm-2-p53 protein complexes. Oncogene 8:2353-2360.

Paech K, Webb P, Kuiper G, Nilsson S, Gustafsson J-A, Kushner P, Scanlan T (1997) Differential ligand activation of estrogen receptors ER $\alpha$ and $\operatorname{Er} \beta$ at AP1 sites. Science 277:1508-1510.

Rabinowicz T, De Courten-Myers GM, Petetot JM-S, Xi G, De Los Reyes E (1996) Human cortex development: Estimates of neuronal numbers indicate major loss late during gestation. J Neuropathol Exp Neurol 55:320-328.

Rabizadeh S, Oh J, Zhong L, Yang J, Bitler C, Butcher L, Bredesen D (1993) Induction of apoptosis by the low-affinity NGF receptor. Science 261:345-348.

Rabizadeh S, Bitler C, Butcher L, Bredesen D (1994) Expression of the low-affinity nerve growth factor receptor enhances $\beta$-amyloid peptide toxicity. Proc Natl Acad Sci USA 91:10703-10706.

Rasmussen J, Torres-Aleman I, McLusky N, Naftolin F, Robbins R (1990) The effects of estradiol on the growth patterns of estrogen receptor-positive hypothalamic cell lines. Endocrinology 126:235-240.

Robertson CN, Roberson KM, Padilla GM, O'Brien ET, Cook JM, Kim C-S, Fine RL (1996) Induction of apoptosis by diethylstilbestrol in hormone-insensitive prostate cancer cells. J Natl Cancer Inst 88:908-917.

Rotello RJ, Hocker MB, Gerschenson L (1989) Biochemical evidence for programmed cell death in rabbit uterine epithelium. Am J Pathol 134:491-495.

Rothman TP, Specht LA, Gershon MD, Joh TH, Teitelman G, Pickel VM, Reis DJ (1980) Catecholaminergic biosynthetic enzymes are expressed in replicating cells of the peripheral but not the central nervous system. Proc Natl Acad Sci USA 77:6221-6225.

Sakaguchi K, Sakamoto H, Lewis M, Anderson C, Erickson J, Appella E, Xie D (1997) Phosphorylation of serine 392 stabilizes the tetramer formation of tumor suppressor protein p53. Biochemistry 36:10117-10124.

Schiebe RJ, Ginty DD, Wagner JA (1992) Retinoic acid regulates both expression of the nerve growth factor receptor and sensitivity to nerve growth factor. J Biol Chem 267:17611-17616.

Shaulian E, Resnitzky D, Shifman O, Blandino G, Amsterdam A, Yayon A, Oren M (1997) Induction of MDM2 and enhancement of cell survival by bFGF. Oncogene 15:2717-2725.

Shughrue P, Dorsa D (1994) Estrogen and androgen differentially modulate the growth-associated protein Gap-43 (neuromodulin) messenger ribonucleic acid in postnatal rat brain. Endocrinology 134:1321-1328.

Shughrue P, Stumpf WE, MacLusky NJ, Zielinski JE, Hochberg RB (1990) Developmental changes in estrogen receptors in mouse cerebral cortex between birth and post weaning studied by autoradiography with 11b methoxy,16a[125]iodoestradiol. Endocrinology 126:1112-1124.

Shughrue P, Scrimo P, Lane M, Askew R, Merchenthaler I (1997a) The distribution of estrogen receptor- $\beta$ mRNA in forebrain regions of the estrogen receptor- $\alpha$ knockout mouse. Endocrinology 138:5649-5652.

Shughrue PJ, Lane MV, Merchenthaler I (1997b) Comparative distribution of estrogen receptor- $\alpha$ and $-\beta$ mRNA in the rat central nervous system. J Comp Neurol 388:507-525.

Singer CA, Rogers KL, Strickland TM, Dorsa DM (1996) Estrogen protects primary cortical neurons from glutamate toxicity. Neurosci Lett 212:13-16.

Singh M, Meyer E, Millard W, Simpkins J (1994) Ovarian steroid deprivation results in a reversible learning impairment and compromised cholinergic function in female sprague-dawley rats. Brain Res 644:305-312.

Singh M, Meyer E, Simpkins J (1995) The effect of ovariectomy and estradiol replacement on brain derived neurotrophic factor messenger ribonucleic acid expression in cortical and hippocampal brain regions of female Sprague-Dawley rats. Endocrinology 136:2320-2324.

Singh M, Sétáló G, Guan X, Warren M, Toran-Allerand CD (1999) Estrogen-induced activation of mitogen-activated protein kinase in cerebral cortical explants: convergence of estrogen and neurotrophin signaling pathways. J Neurosci 19:1179-1188.

Sohrabji F, Greene L, Miranda R, Toran-Allerand CD (1994a) Recip- 
rocal regulation of estrogen and NGF receptors by their ligands in PC12 cells. J Neurobiol 25:974-988.

Sohrabji F, Miranda R, Toran-Allerand CD (1994b) Estrogen differentially regulates estrogen and nerve growth factor receptor mRNAs in adult sensory neurons. J Neurosci 14:459-471.

Sohrabji F, Miranda R, Toran-Allerand D (1995) Identification of a putative estrogen response element in the gene encoding brain-derived neurotrophic factor. Proc Natl Acad Sci USA 92:11110-11114.

Song X, Sheppard H, Norman A, Liu X (1999) Mitogen-activated protein kinase is involved in the degradation of $\mathrm{p} 53$ protein in bryostatin1-induced differentiation of the acute promyelocytic leukemia NB4 cell line. J Biol Chem 274:1677-1682.

Spreafico R, Frassoni C, Arcelli P, Selvaggio M, De Biasi S (1995) In situ labeling of apoptotic cell death in the cerebral cortex and thalamus of rats during development. J Comp Neurol 363:281-295.

Stumpf WH (1969) Nuclear concentration of 3H-estradiol in target tissues: dry mount autoradiography of vagina, oviduct, ovary, testis, mammary tumor, liver and adrenal. Endocrinology 85:31-31.

Taher A, Yanai N, Obinata M (1995) Properties of incompletely immortalized cell lines generated from a line established from temperaturesensitive SV40 T-antigen gene Transgenic mice. Exp Cell Res 219:332-338.

Thomaidou D, Mione M, Cavanagh JFR, Parnavelas JG (1997) Apoptosis and its relation to the cell cycle in the developing cerebral cortex. J Neurosci 17:1075-1085.
Tomkinson A, Reeve J, Shaw RW, Noble BS (1997) The death of osteocytes via apoptosis accompanies estrogen withdrawal in human bone. J Clin Endocrinol Metab 82:3128-3135.

Toran-Allerand CD, Miranda R, Bentham W, Sohrabji F, Brown TJ, Hochberg RB, MacLusky NJ (1992a) Estrogen receptors co-localize with low-affinity nerve growth factor receptors in cholinergic neurons of the basal forebrain. Proc Natl Acad Sci USA 89:4668-4672.

Toran-Allerand CD, Miranda R, Hochberg RB, MacLusky NJ (1992b) Cellular variations in estrogen receptor mRNA translation in the developing brain: evidence from combined 1251-estrogen autoradiography and non-isotopic in situ hybridization histochemistry. Brain Res 576:25-41.

Wang TY, Phang J (1995) Effects of estrogen on apototic pathways in human breast cancer cell line MCF-7. Cancer Res 55:2487-2489.

Woolley CS, McEwen BS (1994) Estradiol regulates hippocampal dendritic spine density via an $N$-methyl-D-aspartate receptor-dependent mechanism. J Neurosci 14:7680-7687.

Woolley CS, Weiland N, McEwen BS, Schwartzkronin PA (1997) Estradiol increases the sensitivity of hippocampal CA1 pyramidal cells to NMDA receptor-mediated synaptic input: correlation with dendritic spine density. J Neurosci 17:1848-1859.

Yanai N, Obinata M (1994) Apoptosis is induced at nonpermissive temperature by a transient increase in p53 in cell lines immortalized with temperature-sensitive SV40 large T-antigen gene. Exp Cell Res 211: 296-300. 